\title{
Assessing the duality of thermal performance and energy efficiency of residential buildings in hot arid climate of Laghouat, Algeria
}

\author{
Darda Bencheikh $^{1}$ D $\cdot$ Madani Bederina ${ }^{2}$
}

Received: 21 May 2019 / Accepted: 28 August 2019 / Published online: 10 September 2019

(C) The Author(s) 2019

\begin{abstract}
Thermal comfort is the main driver of buildings energy consumption; it has been classified by building occupants to be of greater importance compared with visual and acoustic comfort. To respond correctly and quickly to the increase in energy price and pollution, thermal regulations and comfort approaches have emerged. This paper compares the thermal performances and energy demand of a vernacular and a low-income modern dwelling using two major thermal comfort approaches (Givoni's approach and adaptive thermal comfort recommended by The American Society of Heating, Refrigerating and Air-Conditioning Engineers in ASHRAE standards 55-2010) and the energy professional's method presented in the French Thermal Regulations RT2012. It shows the effectiveness of bioclimatic and passive strategies in reducing energy demand, increasing the thermal comfort level for the buildings, and therefore reducing greenhouse emissions. The results show that the vernacular house was comfortable during the warm day, which approved a 100\% cooling energy efficiency (the thermal comfort has been achieved in a passive way), contrary to the contemporary dwelling, in which the use of air-conditioning modern systems was essential to meet the occupant needs in terms of thermal comfort. The difference between the houses' energy performances was estimated, including a $39 \%$ reduction in energy demand.
\end{abstract}

Keywords Vernacular dwelling $\cdot$ Low-income modern house $\cdot$ Thermal comfort $\cdot$ Building simulation $\cdot$ Building energy demand $\cdot$ Hot arid climate

\section{Introduction}

The relatively recent awareness of planet endangerment has forced politicians to take measures to limit $\mathrm{CO}_{2}$ emissions (a gas that absorbs and emits thermal radiation, creating the greenhouse effect, its global emission in Algeria increased 3.98 billion tons) into the atmosphere (Fig. 1) [45]. The construction is key sector to cope with greenhouse gas production, due to its major consumption of fossil fuels with high rates of carbon dioxide emissions into the atmosphere $[47,51,23]$. It is responsible for nearly $40 \%$ of the total $\mathrm{CO}_{2}$ emissions (in other words, 842 million tons of $\mathrm{CO}_{2}$ each year), approximately two-thirds of halocarbon, and $25-33 \%$ of black carbon emissions [21], and $36 \%$ of global

Darda Bencheikh

Bencheikh.darda@yahoo.com

1 ETAP Laboratory, Architecture and Urbanism Institute, Saad Dahleb University, Blida, Algeria

2 SREML Laboratory, Department of Civil Engineering, Ammar Telidji University, Laghouat, Algeria energy consumption $[42,17,15]$ which presents a second threat that we are fighting against.

Nowadays, building energy saving means implementing solutions specified in different regulatory frameworks. The global directive on the energy performance of buildings requires adopting tools for calculating energy performance, applying minimum standards of performance during design, operations, carrying out building certification and ensuring control of heating and cooling systems [7, 26, 31]. Indeed, indoor thermal comfort is considered as a main driver of building energy consumption [52]—it is responsible for almost half of the global energy used in residential buildings (Fig. 2) according to IEA-and one of the energy poverty indicators [27] on the basis of the negative health effects, including excess winter and summer mortality of living in a cold or hot home [25, 32, 49]. It is classified by building occupants to be of greater importance compared with visual and acoustic comfort [19].

In fact, building energy consumption, particularly that of the residential sector, depends, as well, on demographic and socioeconomic characteristics, economic behavior of 


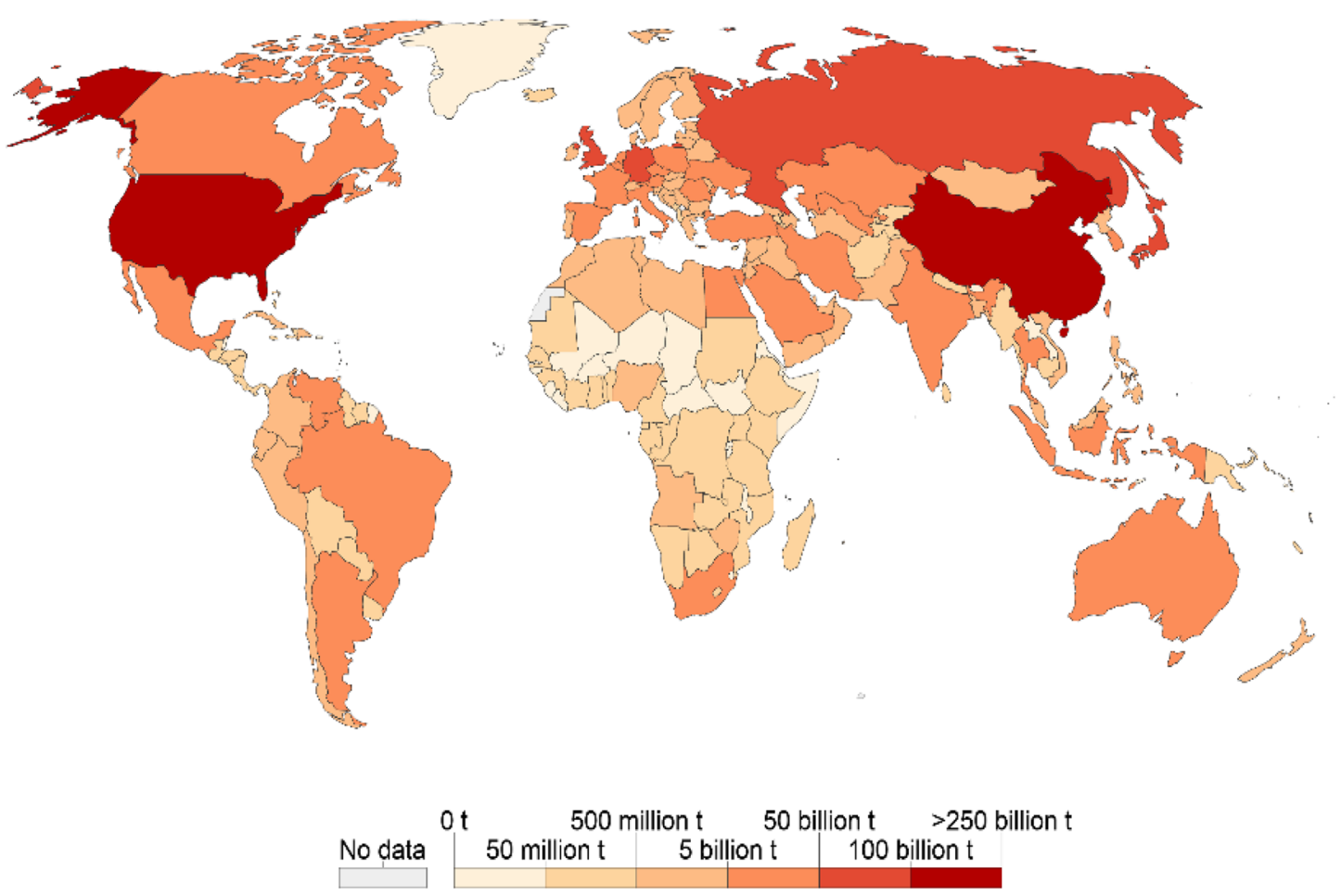

Fig. 1 Cumulative $\mathrm{CO}_{2}$ emissions of each nation from the industrial revolution in 1750 to 2016 [45]

Fig. 2 Residential energy use in different developed countries [21]

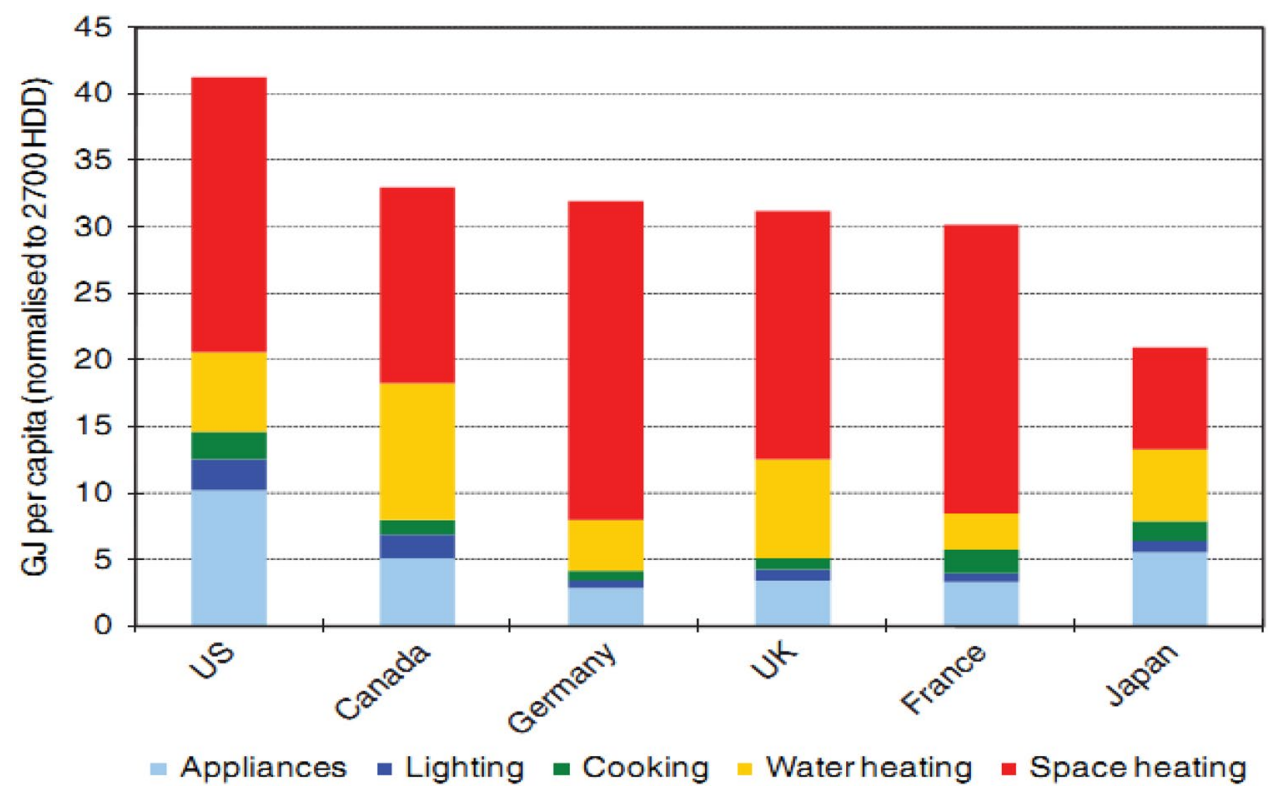

resident households and household composition [5, 6, 34]. A large variance between net energy requirements and the real energy consumption has been unveiled in several research studies (the final energy needed for improving building thermal behavior is always superior to the final energy consumption), which makes the household behavior an important factor that must be taken into consideration, whether in construction, renovation or rehabilitation, to control real energy consumption $[20,24,35]$ and alleviate the energy poverty that is rising rapidly across the world (Fig. 3), a consequence of household income and energy prices (according to the 


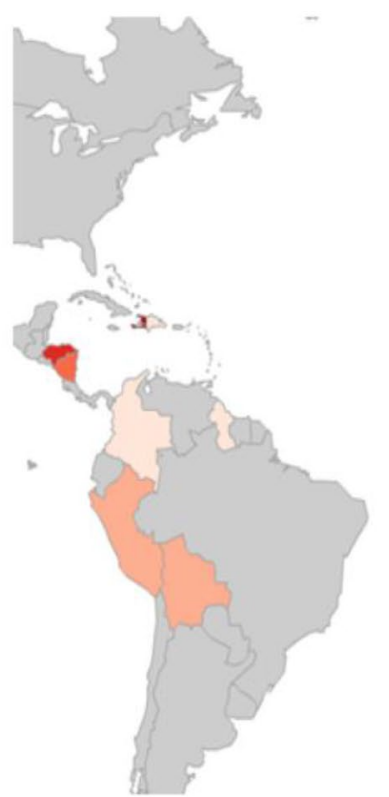

Fig. 3 Multidimensional Energy Poverty Index (Multidimensional Energy Poverty Index is an international measure of acute poverty, based on education, health and living standards. Energy poverty is

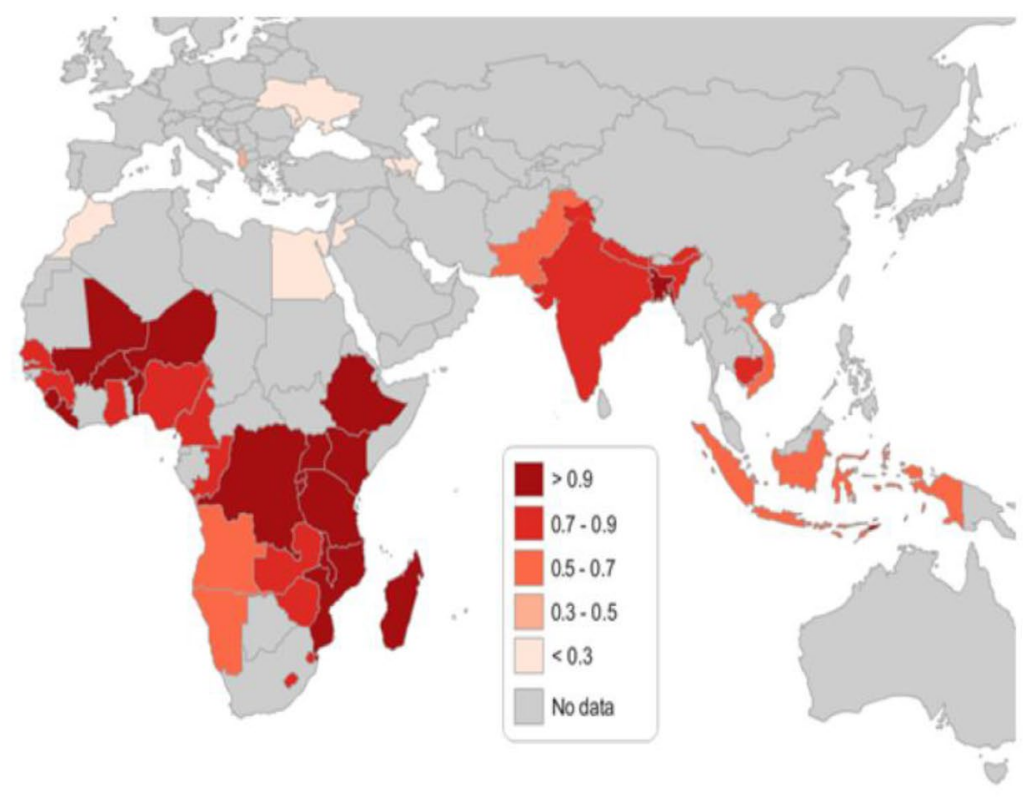

2019 IEA $^{1}$ statistics, 674 million people remain without access to modern energy).

To respond correctly and quickly to the energy price increase and the demand/supply imbalance, thermal regulations (RT, ${ }^{2}$ ASHRAE ${ }^{3}$ standards, ISO ${ }^{4} \mathrm{EPBD}^{5}$. etc.) and comfort approaches (such as that of Givoni) have been emerging. They simply determine a goal of reducing the new buildings' energy consumption [52,9], provide methods to support the assessment of thermal comfort and frame the improvement work in existing buildings, compared to the regulatory standards in force, while basing on passive solutions and bioclimatic strategies that the elders had learned from their experience $[1,11]$. Indeed, meeting the increased energy demand requires, as well, a transformation of energy supply systems; therefore, a greater use of renewable energy (solar, wind, hydroelectric, biomass, and geothermal power) is recommended by those regulations. However, the renewable projects require large investments in infrastructure, which is considered risky and almost impossible in Algeria, unless there is availability of sufficiently funded, consistent incentives. Nonetheless, given the important role that

1 IEA: International energy agency .

${ }^{2}$ RT: French Thermal Regulation.

3 ASHRAE: American Society of Heating, Refrigerating, and AirConditioning Engineers.

${ }^{4}$ ISO: International Organization for Standardization.

${ }^{5}$ EPBD: Energy Performance of Buildings Directive. qualified as acute when MEPI exceed 0.7, moderate between 0.3 and 0.7, and low below 0.3.) [39]

thermal comfort will continue to play in reducing building energy demand, the construction actors have to move toward achieving it through simple design and local building materials, to meet the low-income housing needs in terms of quality than quantity, and prove more effectiveness in the long term.

It is within the framework of this global subject that the present paper highlights the ancient strategies that were revealed in harmony with human physiological function, much more than modern active systems [16], to encourage the construction actors to design houses with the best thermal comfort and the most reduced possible energy cost, while respecting the environment. To achieve this objective, an evaluation of thermal behavior and energy efficiency of two types of dwellings (a vernacular and a low-income modern house) was carried out (considering Givoni's approach to thermal comfort, ASHRAE standards 55-2010 to adaptive thermal comfort, and energy professional's method to energy demand) under the semi-arid climatic conditions of southern Algeria.

\section{Study case}

This work is based on the region of Laghouat $\left(33,46^{\circ}\right.$ north, $2,66^{\circ}$ east) which bears the nickname the 'door of the desert'. It is a city located at the center of the country, $400 \mathrm{~km}$ south of the capital Algiers (Fig. 4) and more than $750 \mathrm{~m}$ above sea level on the highlands. Laghouat is crossed 
Fig. 4 The study area climate ([36] edited by authors)
E 1 litgral

E 2 HIGH PLATEAU

MIUNTAIN

E3 Pre-sahara

TAssill

E 4 sahara

E5 Tanegrauft

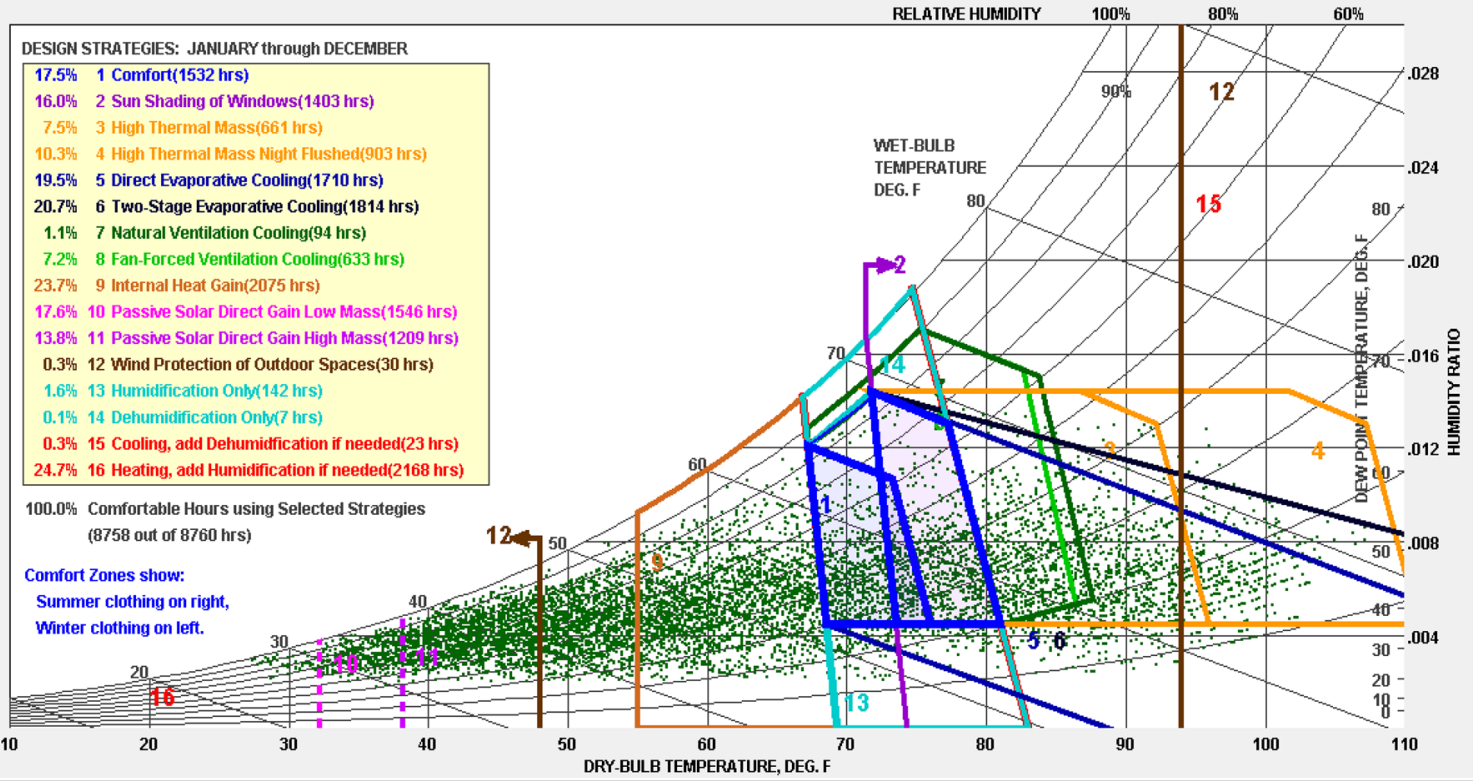

Fig. 5 Psychrometric chart for the city of Laghouat

by the chain of the Saharan Atlas with peaks that exceed $2000 \mathrm{~m}$ (ARIEFF, 2013).

From the relief, the climate is continental in the northwest with rainfall ranging from 300 to $400 \mathrm{~mm}$, snowfall and white frosts. In the highlands region (where the study area is situated), the climate is semi-arid. Rainfall varies between
$150 \mathrm{~mm}$ in the center and $50 \mathrm{~mm}$ in the south. Winters are characterized by white frost and summers by strong heat accompanied by sandstorms [3].

Figure 5 shows the psychrometric chart for the City of Laghouat from Climate Consultant 6.0 (a software that analyzes the weather data for a given city based on the climate 
data that has been determined by Metenorm software-from 2008 to 2017). It has been based on three different attributes of the climate that can be displayed concurrently to show if humans will be comfortable in spaces with these characteristics (the average annual temperature and air relative humidity). The model setting for the climate template was the ASHRAE handbook of fundamental comfort model, 2005 (clothing set for winter was at $1 \mathrm{Clo}^{6}$ and for the summer $0.5 \mathrm{Clo}$, and activity level at daytime was $1.1 \mathrm{Met}^{7}$ ).

This software allowed to identify the number of hours and the percentage of time that falls within 13 different building design strategies range (represented as different colored zones on the chart). It shows that $17.5 \%$ of the hours per year $(1532 \mathrm{~h})$ are in the comfort range.

The best single cooling design strategy is Sun Shading, which accounts for $16.0 \%$ of the house (due to exposure and intense solar radiation). It has the advantage of being able to be combined with all the other cooling strategies. The next most effective cooling strategy is the High Thermal Mass, which accounts for $7.5 \%$ of the hours. Note that if this strategy was combined with Night Flushing, it adds an additional $10.3 \%$ of the hours. Laghouat is not considered as a humid region, but the evaporative cooling strategies have accounted for $40.2 \%$ of the hours. The ventilation strategies could improve thermal comfort for $8.3 \%$ of the hours per year.

On the heating side, $23.7 \%$ of the hours would be comfortable indoors purely because of internal loads (lights, appliances, and occupants). Passive Solar Direct Gain with Low Mass could add an additional $17.6 \%$ of the hours, but if the building was High Mass then Passive Solar Direct Gain could create comfort conditions for only about $13.8 \%$ of the hours. If Wind Protection was provided it could improve thermal comfort for $0.3 \%$ of the hours per year.

However, even under the best of passive heating and cooling conditions at least $24.7 \%$ of the hours per year will require conventional heating $(2168 \mathrm{~h})$, and $0.3 \%$ of them will require conventional cooling ( $23 \mathrm{~h}$ ).

It might be appropriate to briefly summarize that these strategies correspond to the best climatic adaptation, which was, in the past, the result of an encounter between human needs and the building's art.

\section{Studied dwelling description}

The investigation was done on two types of dwellings (Fig. 6a). The first one is a vernacular house made of adobe. It is located in the old Ksar of Laghouat (Ksar Zgag-ElHadjadj). The letter is a set of compact habitat built in

\footnotetext{
${ }^{6}$ Clo: Clothing insulation $\left(\mathrm{m}^{2} \mathrm{~K} / \mathrm{W}\right)$.

${ }^{7}$ Met: Metabolic rate $\left(\mathrm{W} / \mathrm{m}^{2}\right)$.
}

height (Fig. 6b), developed in arborescent frame (over an area of 3 hectares). It comprises 135 houses spread over 11 islets of irregular pentagonal shape oriented north-south. Its urban fabric is structured by squares, streets, alleys and impasses. This Ksar was constructed in 1704 and classified as a national cultural heritage in 2007.

However, the second chosen dwelling is a semi-collective contemporary house, built of hollow brick according to the modern techniques and principles. The urban fabric in which it is located is entirely disparate and burst (Fig. 6c), and its frame is mainly organized of bars defining several unexploited free spaces. The neighborhood was built as part of the participatory social housing program in 2012 (established for the strengthening of the state aid systems to low-income citizens vacillating between 30,000 and 60,000 Algerian dinars).

The low-income modern house is developed on a square plan, whose rooms are aligned around an entrance hall. Its buffer areas are oriented north; however, the living rooms are south facing, contrary to the vernacular dwelling that is characterized by introversion and centrality, and in which the living rooms are aligned around a courtyard and oriented north (Figs. 7, 8). Both dwellings are located on the first floor whose roofs are completely exposed to the hostile climatic conditions.

\section{Materials and methods}

Methodologically, this paper consists in the first place of a qualitative study based on the observation of the study cases, which allowed to collect information and formalize the database that was subsequently used for the quantitative study. The latter implies value collection performed in two steps.

The first stage was aimed to evaluate the houses' thermal behavior; it is founded on an experimental approach based on a measurement operation that is performed using instrumentation. This made it possible to compile the graphical survey of the investigation field and to model it, accompanied by site recordings that aimed to determine the relative humidity and the external and internal air temperatures of the houses. However, the air velocity was not measured hourly, since it was almost stable in the houses with an average of $0.2 \mathrm{~m} / \mathrm{s}$ that is considered as a comfortable value for the occupants [53]. The site measurements were taken by using a thermo-hygrograph (Fig. 9a) with self-contained mechanical recording. This instrument enables to measure the relative humidity by a hair hygrometer (Accuracy: $\pm 2.5 \%$ ) and temperatures by a metal bimetallic strip (accuracy: $\pm 1 \%$ ). The external temperature and relative humidity recordings were obtained on the measurement days (6-7 January and 8-9 July 2017), from the city's meteorological station [41]. 


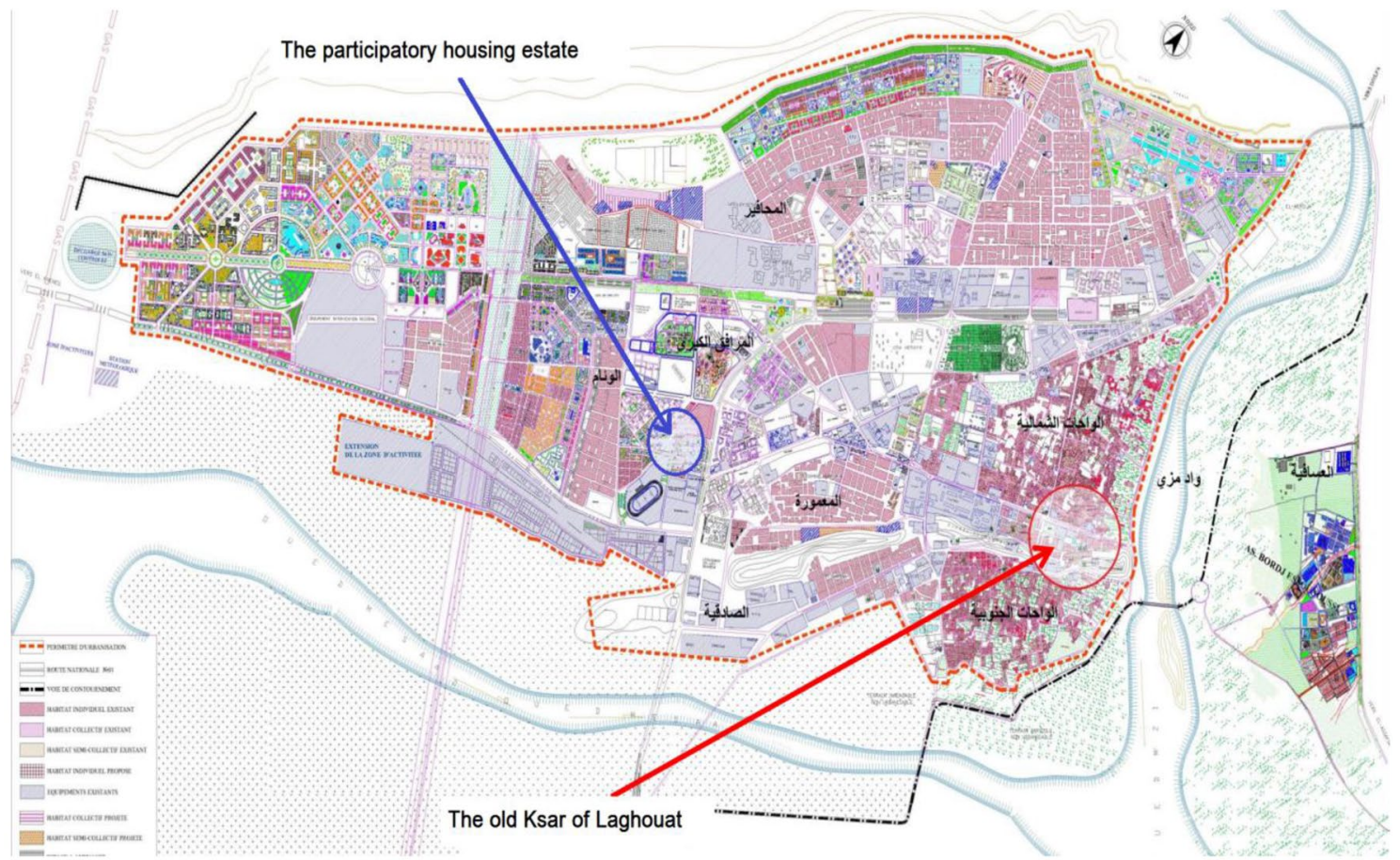

a Situation of study cases (PPSMVSS, 2011).

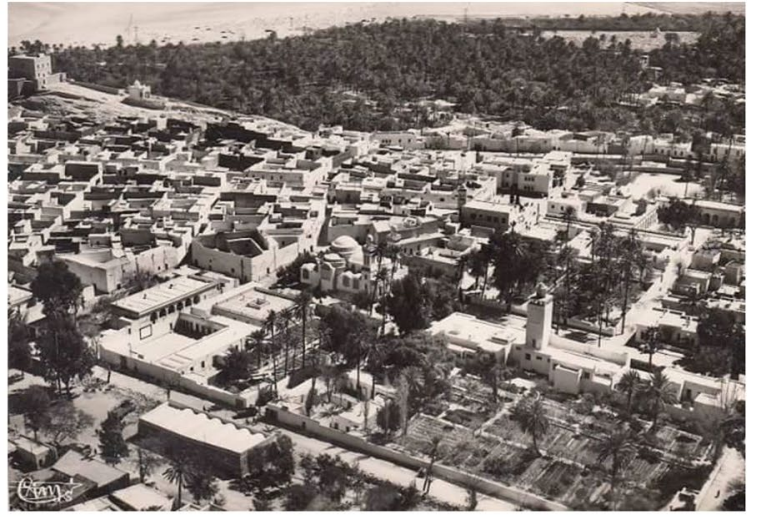

b Old Ksar of Laghouat (PPSMVSS, 2011).

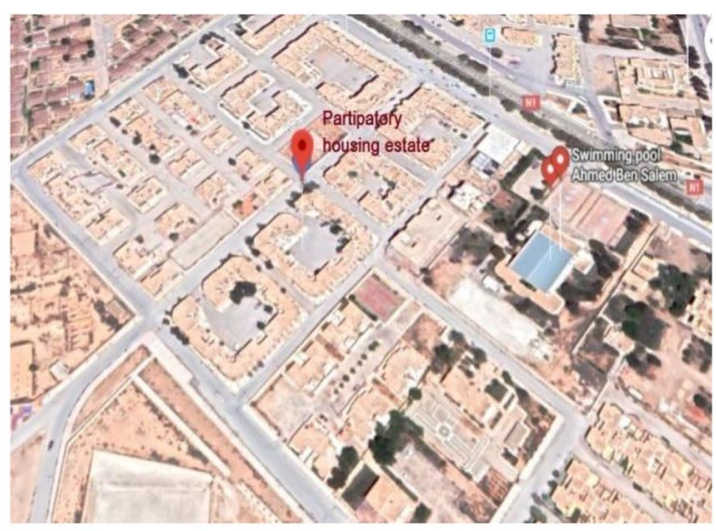

C Participatory housing estate

Fig. 6 Situation of study cases

As there is currently no Algerian standard, to achieve an analysis of thermal comfort in this case study which is as reliable as possible, two types of international directives were used; the Givoni's approach (in which the comfort range was limited between a temperature of 20 and $27{ }^{\circ} \mathrm{C}$ and a relative humidity of $40-70 \%$ ) and ASHRAE standards 55-2010 (in which the comfort temperature is not a fixed value, since it depends on various factors, including air temperature, mean radiant temperature, humidity, air velocity and direction, metabolic rate, and clothing levels). Inhabitant thermal comfort is calculated by measuring the adaptive comfort range, which can be found by Eq. (1) (which defines the upper limit of the comfort area), Eq. (2) (which defines the lower limit of the comfort area) and Eq. (3) (which defines the comfort temperature) $[2,12]$. This range matches $90 \%$ and $80 \%$ acceptability limits and could reach around $30{ }^{\circ} \mathrm{C}$, following the adaptive model in the ASHRAE 55-2017 Standard.

$80 \%$ acceptability higher limits $=T_{\mathrm{c}}+3.5^{\circ} \mathrm{C}$,

$80 \%$ acceptability lower limits $=T_{\mathrm{c}}-3.5^{\circ} \mathrm{C}$.

However, the comfort temperature is as described below $[2,12]$ :

$T_{\mathrm{c}}=17.8+0.31 T_{\mathrm{o}}$, 

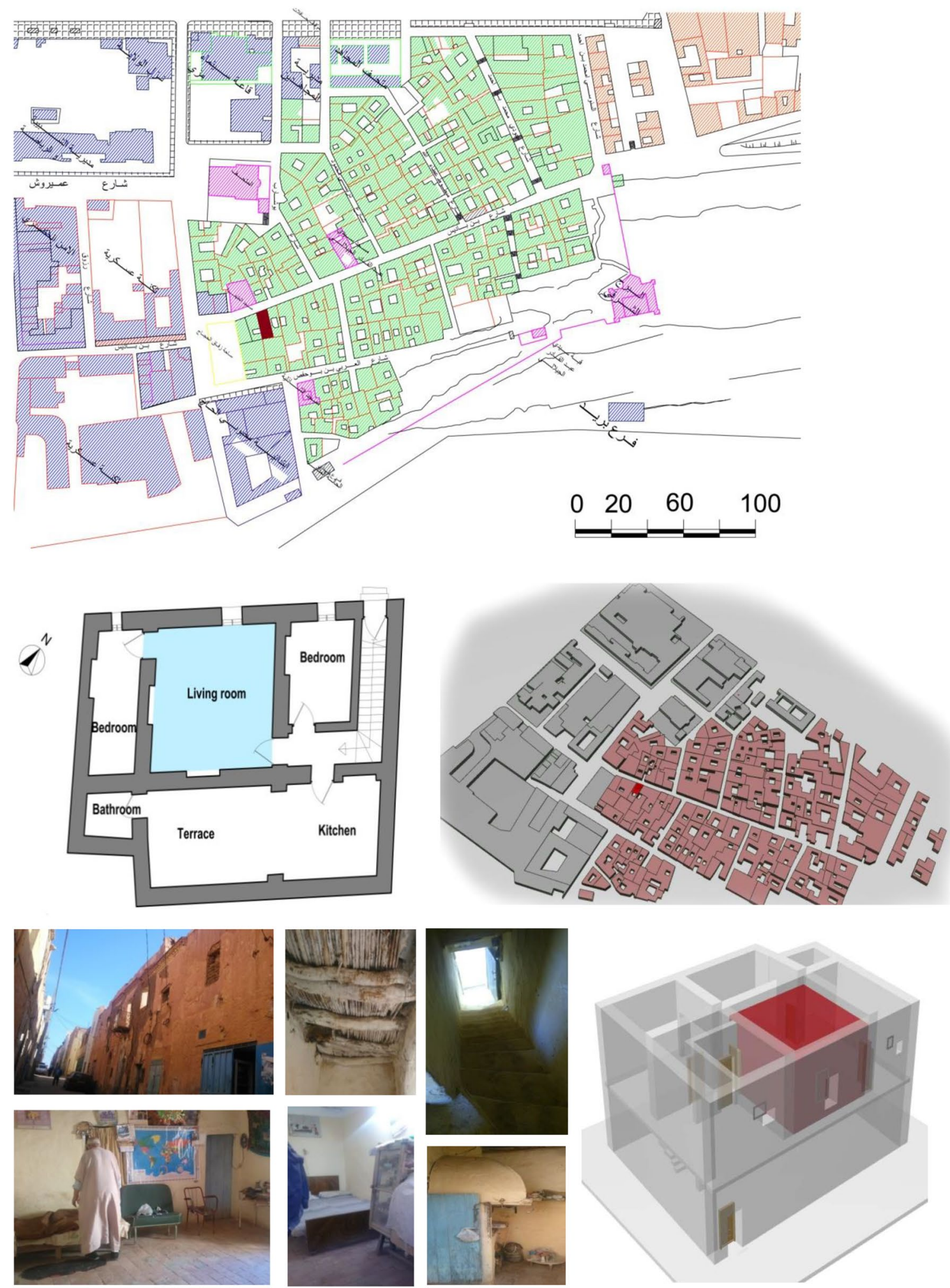

Fig. 7 The studied vernacular dwelling 

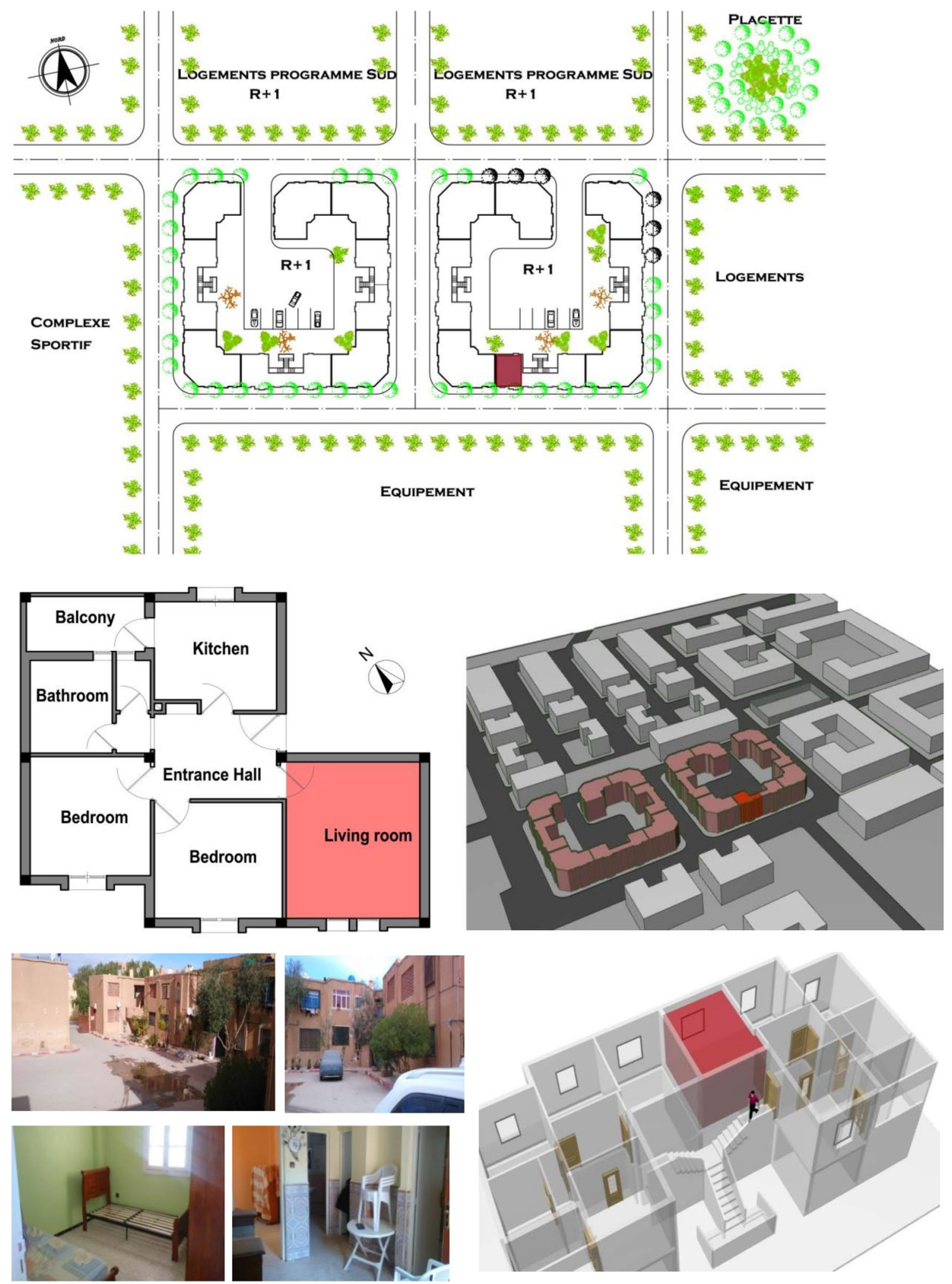

Fig. 8 The studied contemporary house 

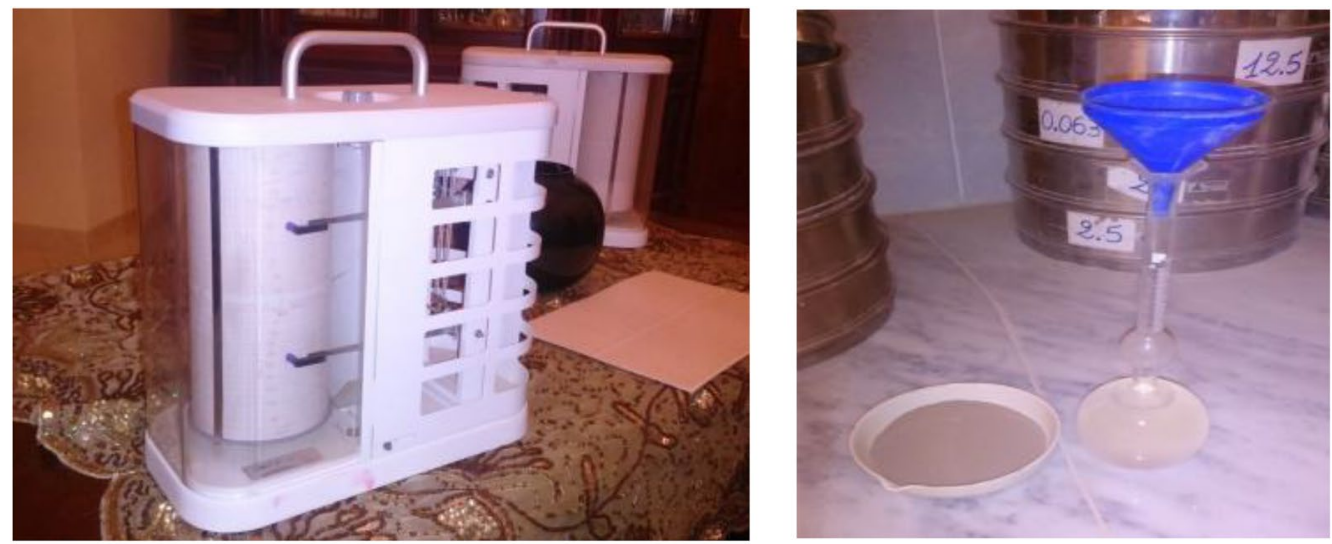

a Thermohygrograph

b Volumenometer

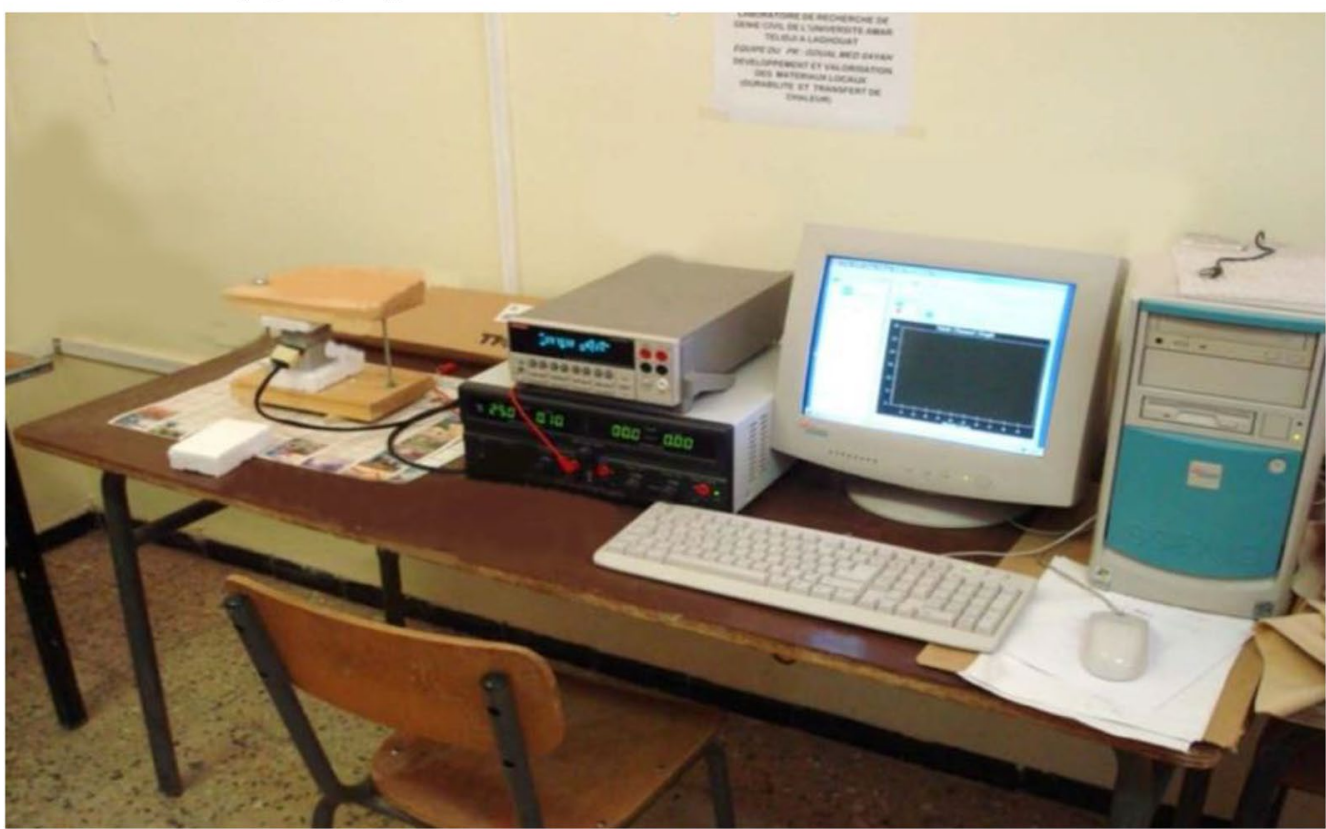

c Experimental setup of thermal conductivity and specific heat measurement.

Fig. 9 Survey and characterization instruments

where $T_{\mathrm{o}}$ is the average of daily outdoor air temperature $\left({ }^{\circ} \mathrm{C}\right) . T \mathrm{c}$ is the comfortable temperature $\left({ }^{\circ} \mathrm{C}\right)$.

The thermal comfort assessment was followed by a building simulation achieved by EnergyPlus software (version 9.1.0), to validate the results and to check the software performances. The simulation of this software required the building materials' thermophysical characteristics. The thermal conductivity and the specific heat of the vernacular dwelling building materials were determined by using the hot wire method [37], which consists of the application of a heat shock by a Kapton ${ }^{8}$ probe placed between two samples, and monitoring the evolution of temperature over time by a mathematical processing software (Fig. 9c).

\footnotetext{
8 Kapton: An insulating and high temperature resistant polyimide film used in the electrical and electronic field.
}

The characterization was done on adobe samples taken from the study Ksar, including the walls of the ksourian houses. The test required the preparation of samples of standardized geometries and sizes $(40 \times 40 \times 20 \mathrm{~mm}$ in size $)$. The adobe extracted from the Ksar was cut to obtain the dimensions envisaged for the test, taking care not to modify the structure or real state of the material and to preserve as much as possible its thermophysical behaviors similar to that of the site.

The density of the building materials is thus indispensable for the numerical simulation; this characteristic was determined by a volumenometer (Fig. 9b) Chatelier (NF P94/064, 1993). The test consists in measuring the displacement of inert liquid level (Ethanol) contained in a narrow-necked 
Table 1 Thermal resistances of internal and external surface exchanges $\left(\mathrm{m}^{2}{ }^{\circ} \mathrm{C} / \mathrm{W}\right)[10]$

\begin{tabular}{|c|c|c|c|c|}
\hline & \multicolumn{2}{|c|}{$\begin{array}{l}\text { Wall in contact with } \\
\text { Outdoor } \\
\text { Open local }\end{array}$} & \multicolumn{2}{|c|}{$\begin{array}{l}\text { Wall in contact } \\
\text { with } \\
\text { Closed local } \\
\text { Crawl space }\end{array}$} \\
\hline & $1 / \mathrm{hi}$ & $1 /$ he & 1/hi & $1 /$ he \\
\hline Vertical wall $>60^{\circ}$ & 0.11 & 0.06 & 0.11 & 0.11 \\
\hline $\begin{array}{l}\text { Horizontal wall } \leq 60^{\circ} \text {, } \\
\text { ascending flow (roof) }\end{array}$ & 0.09 & 0.05 & 0.09 & 0.09 \\
\hline $\begin{array}{l}\text { Descending flow (low- } \\
\text { level floor) }\end{array}$ & 0.17 & 0.05 & 0.17 & 0.17 \\
\hline
\end{tabular}

container, when $64 \mathrm{~g}$ of adobe powder (at a temperature of $20 \pm 1^{\circ} \mathrm{C}$ ) is introduced therein.

The second step was that of the daily energy demand estimation, which was achieved by following the calculation formulas of the air-conditioning and heating energy demand, presented in the French thermal regulations [46]. It allowed determining the energy needed in the evaluated spaces, to reach the comfort minimum temperature of summer and that of winter.

The formulas were based on the unified degree days (UDD) calculated following the energy professional's method-Eq. (1)—(Scientific and Technical Committee of Climatic Industries-COSTIC) [46].

$B=24 \times G \times V \times \mathrm{UDD}$,

where $B$ is the daily energy demand ( $\mathrm{W} \mathrm{h}), G$ is the volumetric loss coefficient $\left(\mathrm{W} / \mathrm{m}^{3}{ }^{\circ} \mathrm{C}\right), V$ is the habitable volume $\left(\mathrm{m}^{3}\right)$, and UDD is the unified degree days $\left({ }^{\circ} \mathrm{C}\right)$.

The volumetric loss coefficient can be calculated with the following equation [10]:

$G=\frac{P}{V}$

However, $P$ presents the thermal losses $\left(\mathrm{W} /{ }^{\circ} \mathrm{C}\right)$ that can be determined using the following experimental correlation [10]:

$P=\sum(K \times S)$

where $K$ is the transmission coefficient $\left(\mathrm{W} / \mathrm{m}^{2}{ }^{\circ} \mathrm{C}\right)$ and $S$ the surface $\left(\mathrm{m}^{2}\right)$.

$\frac{1}{K}=\sum \frac{1}{R}+\left(\frac{1}{h e}+\frac{1}{h i}\right)$,

where $R$ is the thermal resistance $\left(\mathrm{m}^{2}{ }^{\circ} \mathrm{C} / \mathrm{w}\right)$.

$\frac{1}{h e}+\frac{1}{h i}$ is the thermal resistances of the internal and external surface exchanges $\left(\mathrm{m}^{2 \circ} \mathrm{C} / \mathrm{W}\right)$. See Table 1 .

$R=\sum \frac{e}{\lambda}$ where $e$ is the building material thickness $(\mathrm{m})$, and $\lambda$ is the thermal conductivity $\left(\mathrm{W} / \mathrm{m}{ }^{\circ} \mathrm{C}\right)$.

The unified degree days can be calculated with the following equations [18]:

$\mathrm{UDD}($ Cooling $)=\left(T_{\max }-T_{\text {ref }}\right) \times\left(0.08+0.42 \times \frac{T_{\max }-T_{\text {ref }}}{T \max -T_{\min }}\right)$,

$\mathrm{UDD}($ Heating $)=\left(T_{\text {ref }}-T_{\min }\right) \times\left(0.08+0.42 \times \frac{T_{\text {ref }}-T_{\min }}{T_{\max }-T_{\min }}\right)$,

where $T_{\max }$ is the daily outdoor maximum temperature $\left({ }^{\circ} \mathrm{C}\right)$, $T_{\text {ref }}$ is the winter or summer reference temperatures (which are equal to $80 \%$ acceptability higher limit in summer and to $80 \%$ acceptability lower limit in winter), and $T_{\min }$ is the daily outdoor minimum temperature $\left({ }^{\circ} \mathrm{C}\right)$.

The results were subjected, thereafter, to a comparative evaluation, to determine finally the difference between the thermal and energetic performances of the two evaluated building types, by an experimental approach.

\section{Study zone geometries and constructive systems}

The study set parameters affecting thermal comfort (common between the two samples) that are not associated with architectural and urban designs or constructive systems, i.e. the number of walls exposed to climatic conditions, the number of openings, the house's occupancy (3 occupants) and their condition (they have not been the subject of a transformation, a restoration or rehabilitation), and the absence of heating or cooling active systems, for the purpose of comparing modern and vernacular construction principles.

The investigation was conducted in representative living rooms of the examined dwellings (Figs. 7 and 8), and their selection was based on exposition to climatic condition (two exposed wall) and absence of active heating and cooling systems. The constructive system elements of study zones are shown in Tables 2 and 3.

\section{Results and discussion}

\section{Thermal performances considering Givoni's approach to thermal comfort}

\section{Site measurements}

The measuring devices were placed at the center of the evaluated spaces at a height of $0.6 \mathrm{~m}$. All the house occupants 
Table 2 Contemporary house construction details [10]

\begin{tabular}{lllll}
\hline Construction details & Building material & Density $\left(\mathrm{kg} / \mathrm{m}^{3}\right)$ & $\begin{array}{l}\text { Thermal conduc- } \\
\text { tivity }\left(\mathrm{w} / \mathrm{m}{ }^{\circ} \mathrm{C}\right)\end{array}$ & $\begin{array}{l}\text { Specific } \\
\text { heat }(\mathrm{J} / \\
\left.\mathrm{kg}{ }^{\circ} \mathrm{C}\right)\end{array}$ \\
\hline Wall & Cement coating & $1700-1900$ & 0.7 & 850 \\
& Hollow brick & 900 & 0.48 & 936 \\
& Air gap & Thermal resistance is & \\
& Hollow brick & $0.16 \mathrm{~m}^{2}{ }^{\circ} \mathrm{C} / \mathrm{W}$ & & 936 \\
& Plaster coating & 750 & 0.48 & 936 \\
Ceiling & Sand & 1300 & 0.35 & 823 \\
& Hybrid mortar & 1900 & 0.6 & 1080 \\
& Sloping concrete & 1450 & 1.15 & 1080 \\
& Hollow body slab & 1300 & 1.45 & 1080 \\
Platform & Plaster coating & $750-1000$ & 1.1 & 936 \\
& Backfill & 2580 & 0.35 & 936 \\
& Concrete floating slab & 2200 & 2.4 & 936 \\
& Cement mortar & 2200 & 1.3 & 1080 \\
& Ceramic tiling & 2200 & 1.4 & 936 \\
\hline
\end{tabular}

Table 3 Vernacular house construction details

\begin{tabular}{lllll}
\hline Construction details & Building material & Density $\left(\mathrm{kg} / \mathrm{m}^{3}\right)$ & $\begin{array}{l}\text { Thermal conduc- } \\
\text { tivity }\left(\mathrm{W} / \mathrm{m}{ }^{\circ} \mathrm{C}\right)\end{array}$ & $\begin{array}{l}\text { Specific } \\
\text { heat }(\mathrm{J} / \\
\left.\mathrm{kg}{ }^{\circ} \mathrm{C}\right)\end{array}$ \\
\hline Wall & Lime mortar & 1800 & 0.87 & 1080 \\
& Adobe brick & $\mathbf{2 5 6 7 . 6}$ & $\mathbf{0 . 8 1 7}$ & $\mathbf{1 0 7 5 . 1}$ \\
& Earth mortar & 1000 & 0.32 & 830 \\
Ceiling & Palm trunk & 390 & 0.085 & 1140 \\
& Reed & 200 & 0.06 & 2088 \\
& Earth layer & $1700-2000$ & 1.15 & 1080 \\
& Lime mortar & 1800 & 0.87 & 1800 \\
Platform & Backfill & 2580 & 2.4 & 936 \\
& Bedding mortar & 2200 & 1.4 & 1080 \\
& Paving with baked clay & 2000 & 0.47 & 936 \\
\hline
\end{tabular}

Bold represents the essential building material that has been characterized (Adobe extracted from the Ksar) were adults, so there was no objective risk of possible manipulations that could distort the recordings.

\section{- Warm day}

The site measurement results presented in the graph below (Fig. 10) show that the vernacular house internal temperature was almost constant throughout the day, with a low amplitude of $1.5^{\circ} \mathrm{C}$ between its maximal and minimal value, $28{ }^{\circ} \mathrm{C}$ and $26.5^{\circ} \mathrm{C}$ (recorded at 4 a.m. and 10 a.m., respectively), contrary to the external temperature, whose amplitude extended from $17^{\circ} \mathrm{C}$ to a maximum temperature of $41{ }^{\circ} \mathrm{C}$. This stability is reflected by the thermal capacity of the material constituting the envelope (adobe brick) and its thickness of $65 \mathrm{~cm}$, which allowed amortization of the external heat inputs [33], by lowering their penetration through the walls. Indeed, the roof system integrated by the original builder of this house was also the subject of thermal insulation [40], whose beams were from the trunk of the palm or joist of poplar, on which seat reeds protected by a layer of earth acting as a cover.

The principle of traditional building materials is to accumulate daytime heat and restore it during the night, while the inhabitant ventilates the space naturally to evacuate the 
Fig. 10 Variation of summer temperature

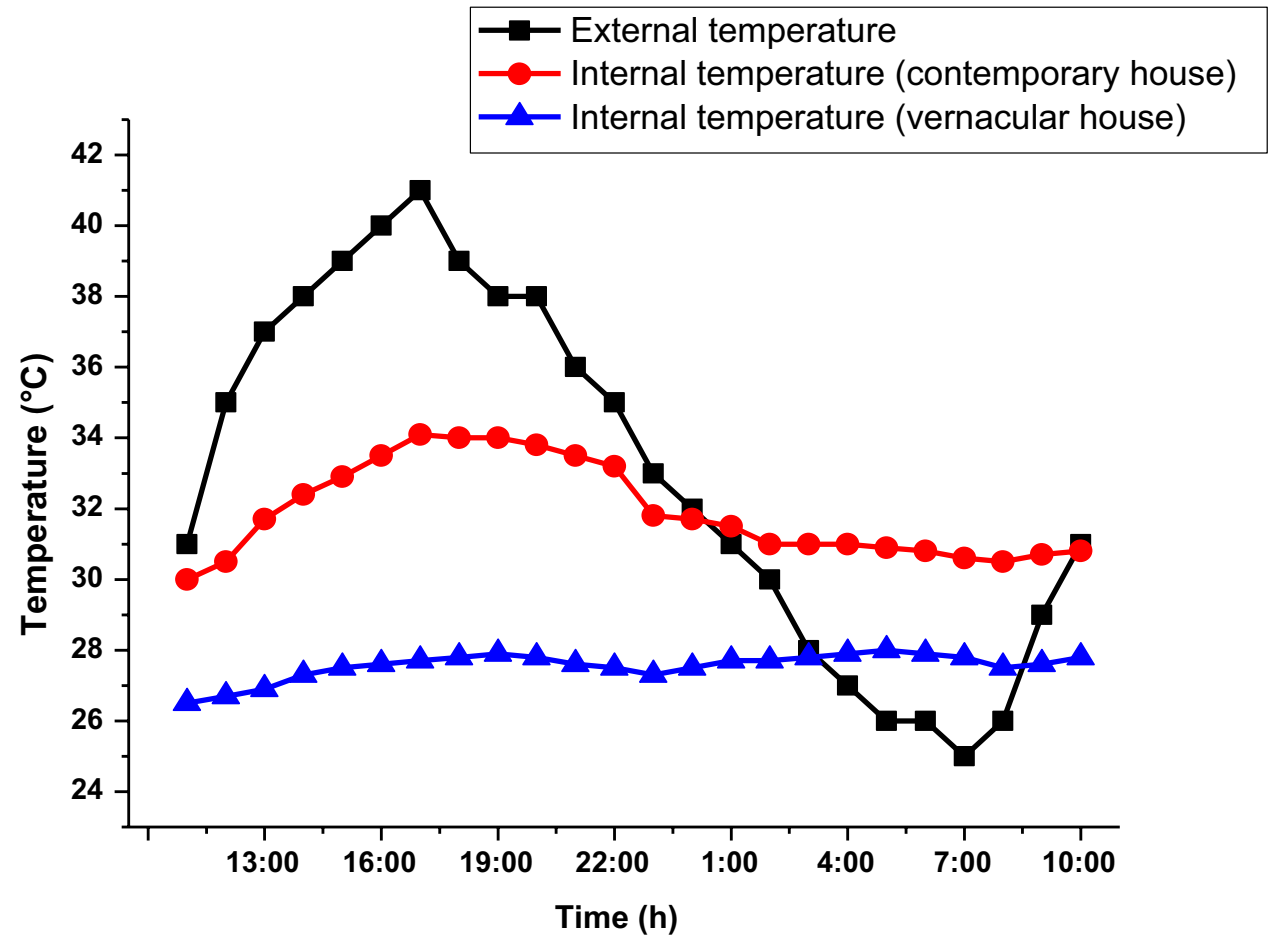

restored heat. This is clearly established from the results, of which a temperature increase was marked at 7 p.m., contrary to the external temperatures which were decreasing. It is noted that the compactness of the urban tissues has also played a significant role in achieving these results, by protecting the walls from direct solar beams [44].

The courtyard is also one of the architectural systems found in the earthen vernacular habitat, which has allowed to change the house microclimate. It works on the principle that the warmed air (by the sun rays and the accumulated heat in the walls) is gradually brought up and replaced by the fresh air, which is accumulated in the courtyard in laminar layers and infiltrated into the adjacent spaces to refresh them. In the morning, the courtyard remains in the shade thanks to the walls that surround it. The courtyard air, therefore, remains cool; nonetheless, it begins to warm up when it is reached by the direct solar radiations [16].

The internal temperature measured in the contemporary house shown in Fig. 10 reveals an amplitude of $4{ }^{\circ} \mathrm{C}$, with a minimum temperature of $30^{\circ} \mathrm{C}$. Observation of the plotted temperature curves revealed that its values followed the pattern of the external temperature variations. This shows that the envelope building materials, especially the roof materials (hollow body), are not well adapted to such climate (hot arid) to ensure summer thermal comfort, added to the southwest orientation of the studied space window (contrary to the studied vernacular space, whose window is oriented northeast) and that of its walls (northeast and southwest), plus the absence of neighborhood buildings which protect them from the solar beams.

Returning to the psychrometric chart of Givoni (Fig. 5), the thermal inertia and the night ventilation are the recommended solutions for any architectural design, under the climatic conditions of July in the region of Laghouat. These two parameters are part of the vernacular house principles, whose resulting daily temperatures were pleasant and in the range of comfort that was limited by Givoni between 20 and $27^{\circ} \mathrm{C}$. However, this house cannot be considered thermally comfortable, without the evaluation of its relative humidity. The graph presented below (Fig. 11) illustrates the relative humidity variations in the two studied samples.

The relative humidity rate was stable in the vernacular house, with a difference of $5 \%$, between its maximum and minimum value (Fig. 11), explained by the hygrometric regulating effect of adobe, which allows a hygrometry around the optimal comfort zone of $40 \%$ to $70 \%$ [22]. The adobe brick can thus capture $3 \%$ of its weight in water vapor, and up to $13.2 \mathrm{~kg}$ of water is absorbed by $1 \mathrm{~m}^{2}$ of $22 \mathrm{~cm}$ wall thickness. The water vapor is then returned to the room when the relative humidity decreases [28]. On the other hand, the hygrometric behavior of the contemporary house was drier, and the relative humidity rate fluctuated slightly between $27 \%$ and $32 \%$. 
Fig. 11 Variation of summer relative humidity
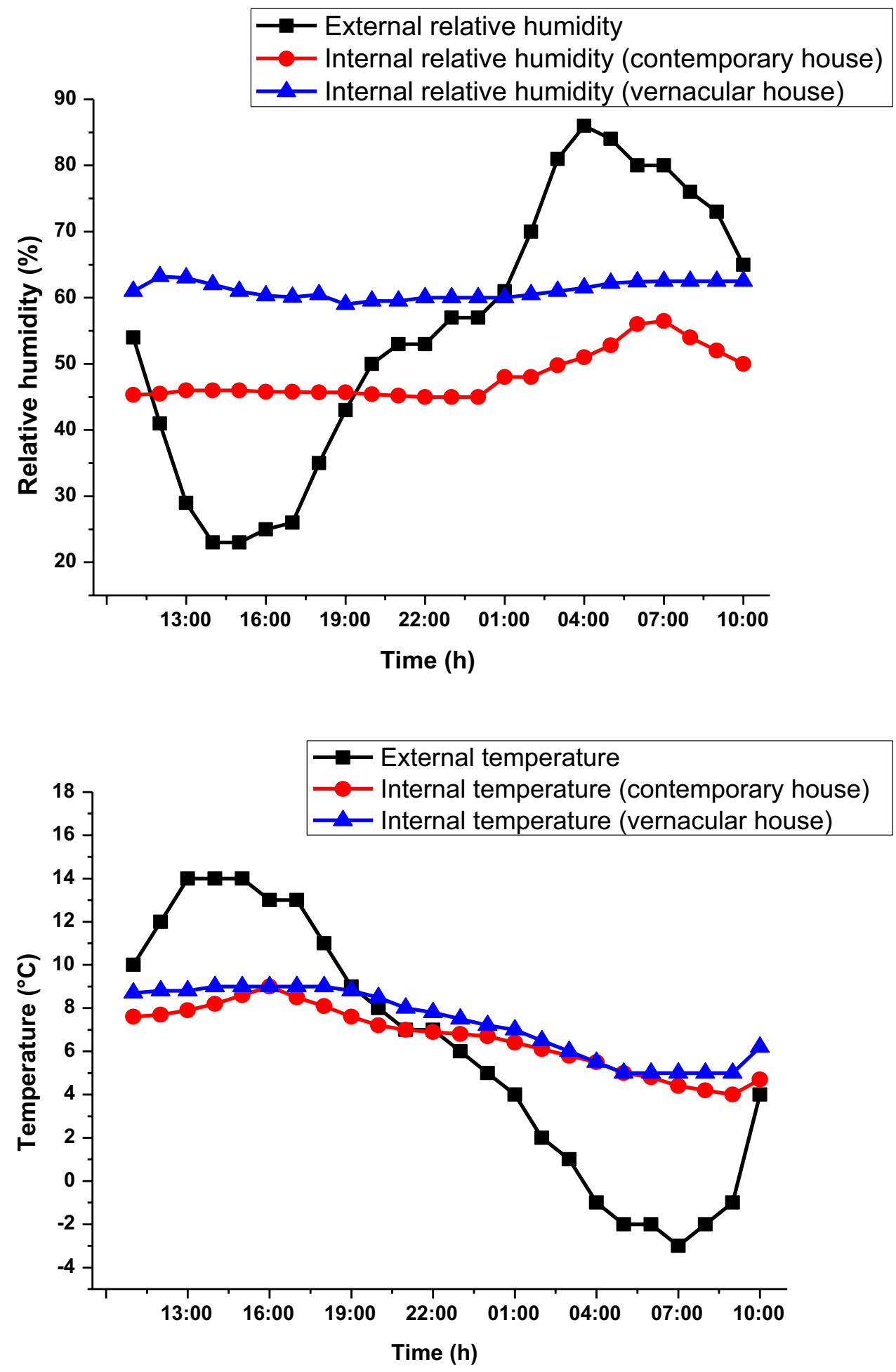

Fig. 12 Variation of winter temperature

\section{- Cold day}

In winter, the adobe brick also benefited from the free solar gain by storing the heat during the day and restituting it at night, thus avoiding a too low temperature in the early hours. This is clearly established by the results shown in
Fig. 12, where the outside temperature was about $-3{ }^{\circ} \mathrm{C}$, when the indoor was $5{ }^{\circ} \mathrm{C}$. Due to its low thermal diffusivity, of the order of $0.76 \mathrm{~m}^{2} / \mathrm{s}$ (a value that was measured by the hot wire test), the adobe brick offered the advantage of an amortization and a significant phase shift of the variations and external thermal contributions (the lower the diffusion, 
Fig. 13 Variation of winter relative humidity

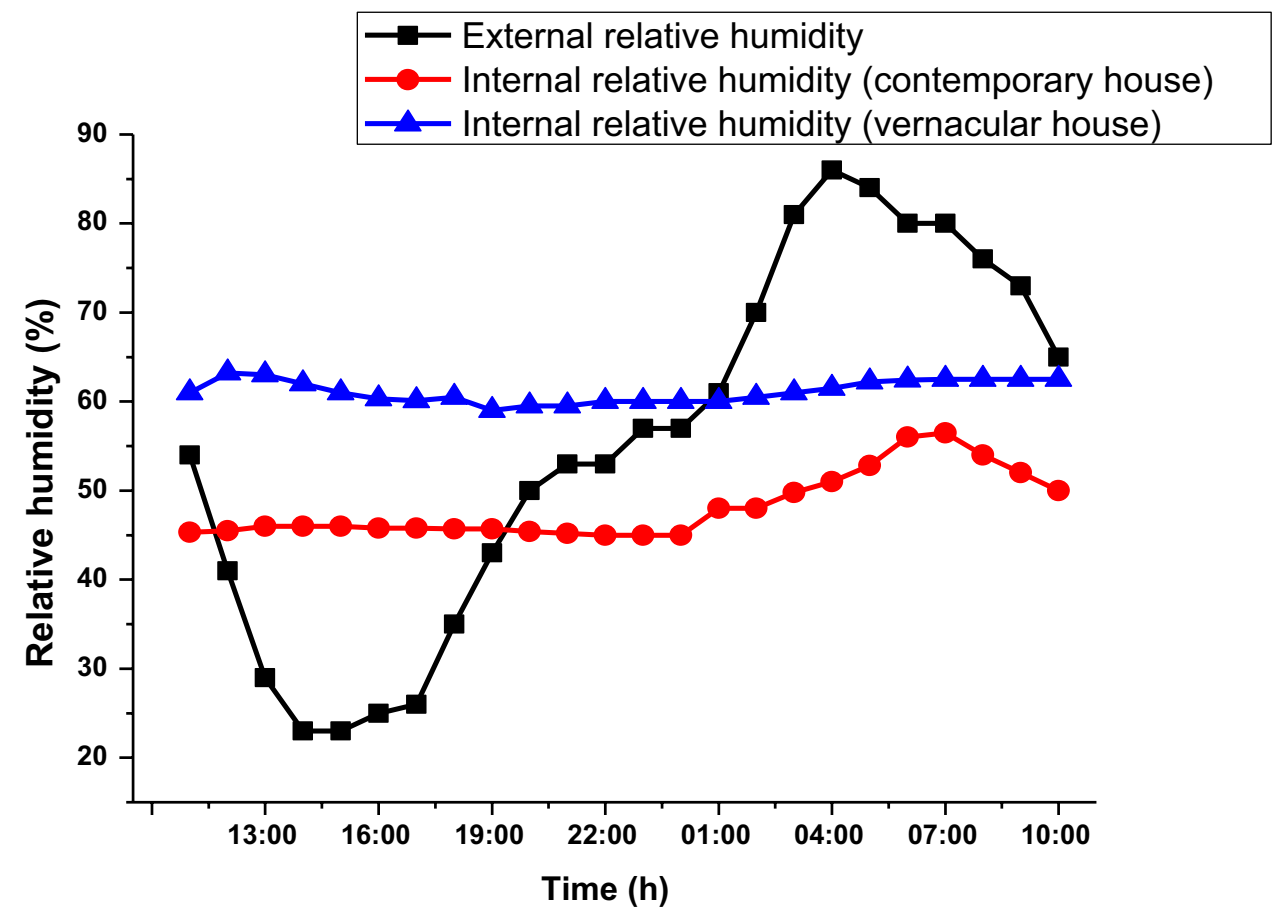

the more time it takes for cold to pass through the material). This justifies the results obtained during the afternoon, whose temperature difference between the inside and outside reached $5{ }^{\circ} \mathrm{C}$ (with an external temperature of $14{ }^{\circ} \mathrm{C}$ and an internal one of $9^{\circ} \mathrm{C}$ ).

The earthen constructions are generally characterized by small and few openings. This last point, where the opening ratio is low with regard to the total surface, has the effect of creating a compact home capable of limiting thermal losses in winter. But this is not the case in the vernacular house study object; the assessed room consisted of a window $1.02 \mathrm{~m}^{2}$, which caused a loss of internal inputs. To all this must be added the north orientation of the window and the wall in which it is placed, and also the number of walls exposed to winter hostile climatic conditions.

As previously mentioned, the brick, thanks to the clay it contains, has a great absorbency that allows it to soak up water vapor until a hygroscopic balance is established between the material and the air. This power allowed to reduce the relative humidity rate in the vernacular room from 84 to $52 \%$ to ensure a kind of stability in its hygrothermal environment, unlike the contemporary room whose humidity rate was about $72 \%$ (Fig. 13).

\section{Building thermal dynamic simulation}

The thermal dynamic simulation is increasingly used today in the design phase, to verify the adequacy of the designed project with respect to the criteria of the thermal and energy performance. This simulation assumes that the results correctly represent the buildings' real behavior. To confirm this principle, a comparative study between the site measurements and numerical simulation results is necessary.

This part of the work was carried out by "EnergyPlus" software, which has shown its performance and has been the subject of extensive validations $[48,4,30]$. The use of this software requires the input of several parameters concerning houses and their surroundings, namely, the urban fabric (Fig. 14a), the architectural typology (Fig. 14b, c), the construction system and building material properties (Tables 2 , 3 ), the window glass features (Table 4), the climate, the natural ventilation, the infiltration rate (the EnergyPlus defaults are 1.0.0.0 which gives a constant volume flow of infiltration under all condition; see Table 5), the air-conditioning and heating, active systems, the occupancy, and the inhabitants' lifestyle. These parameters affect the house's performance, so it is important to identify them in a detailed manner to ensure an excellent level of thermal behavior and energy requirement accuracy.

The adobe brick constituting the vernacular house envelope was subjected to a characterization test, to determine its thermophysical properties necessary for the simulation. This material presents a state of important alteration due to climatic changes and especially to aging, which is clearly established from the results obtained showing a thermal conductivity of $0817 \mathrm{w} / \mathrm{m}{ }^{\circ} \mathrm{C}$. The latter is composed of a percentage of straw, which allows obtaining better thermal conductivity. After a certain lapse of time, the straw rots 


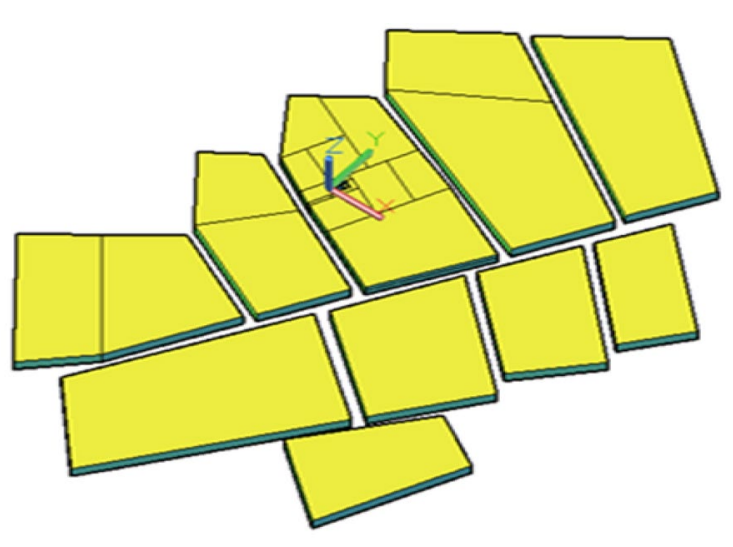

a Studied Ksar.

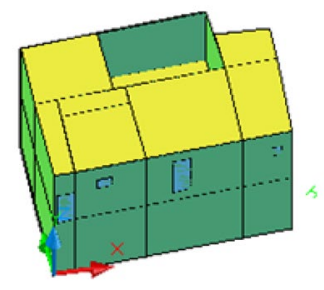

b Vernacular dwelling.

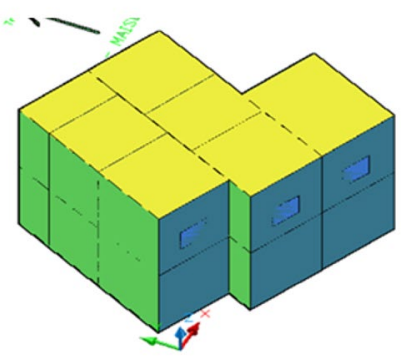

c Modern dwelling.

Fig. 14 3D views made by EnergyPlus software

(this was noticed during the characterization of the adobe, where the amount of straw was almost zero), which increases the thermal conductivity of the adobe and influences its durability [13].

The site measurement and numerical simulation comparison (Tables 6,7 ) show a small average relative error of $2.3 \%$ between the measured and simulated results (Eq. 11). This translates into the homogeneity of building materials that have been assumed by the software. However, reality presents a significant state of aging. This uncertainty may also be related to the positioning of the measuring instrument and its accuracy.

Error percentage $=\frac{\text { measured value }- \text { simulated value }}{\text { measured value }} \times 100$.

Evaluating the accuracy of the simulation results is a significant point. EnergyPlus presented a good agreement of the numerical method, results and experimental test in terms of ambient temperature and relative humidity, which allow determining the mean radiant temperature used to evaluate the adaptive comfort, according to the operative temperature (average between the mean radiant temperature and the mean air temperature) considering the ASHRAE Standard.
The summer mean radiant temperature results $\left(28.45^{\circ} \mathrm{C}\right.$ and $25.9{ }^{\circ} \mathrm{C}$ in vernacular and contemporary house, respectively) were lower than the outdoor mean temperature $\left(33^{\circ} \mathrm{C}\right)$. Moreover, these surface temperature values support the idea of the thermal mass effectiveness as an environmental design strategy that depends on a series of parameters, such as the building material choice, the wall surface and its solar absorptivity. In contrast, the mean radiant temperatures of cold days were higher than the outdoor mean temperature $\left(5.9^{\circ} \mathrm{C}\right)$ in the two study cases $\left(7.67^{\circ} \mathrm{C}\right.$ and $6.58{ }^{\circ} \mathrm{C}$ in the vernacular and contemporary house, respectively).

\section{Adaptive thermal comfort (considering ASHRAE Standard 55-2010)}

The adaptive model offers broader thermal comfort zones, ranging from $25.5^{\circ} \mathrm{C}$ to $30.5^{\circ} \mathrm{C}$ in summer and $17.1^{\circ} \mathrm{C}$ to $22.1^{\circ} \mathrm{C}$ in winter. Thus, it can be concluded that the operative temperature of the contemporary house $\left(30.2^{\circ} \mathrm{C}\right)$ is almost outside of the zone of acceptability (during the warm day). Nevertheless, the comfort was almost assured inside the vernacular house, in which the operative temperature was $26.4^{\circ} \mathrm{C}$ (Fig. 15).

Givoni's approach has shown that the thermal comportment of the two evaluated houses was outside the comfort range during the typical cold day, in which the use of active heating systems was essential, to obtain suitable and stable ambient temperatures. This result was also confirmed by the adaptive thermal comfort approach. The operative temperature results $\left(7.6^{\circ} \mathrm{C}\right.$ and $6.5^{\circ} \mathrm{C}$ recorded in the vernacular and contemporary house, respectively) and the adaptive thermal range demonstrate a large difference of $10^{\circ} \mathrm{C}$. This requires an in-depth reflection on the active heating system to be used in the two buildings.

It should be recalled, in this regard, that the traditional vernacular design was much more intended for warm period. However, the contemporary design has often been linked to meet the housing needs in the short term (favoring quantity over quality) which proves to be less effective or even counterproductive in the medium and long term.

\section{Energy demand (considering the energy professional's method)}

The calculation of building energy demand takes into account the climate of the region in which it is located, the volume to be cooled or heated and its loss coefficient. The results provide the basis for estimating energy need due to air-conditioning and heating in both rooms evaluated. Tables 8 and 9 give the thermal resistances of their constructive elements. 
Table 4 Window glass features [10]

\begin{tabular}{lllll}
\hline $\begin{array}{l}\text { Window } \\
\text { detail }\end{array}$ & $\begin{array}{l}\text { Thickness } \\
(\mathrm{m})\end{array}$ & $\begin{array}{l}\text { Thermal } \\
\text { conductivity } \\
\left(\mathrm{w} / \mathrm{m}^{\circ} \mathrm{C}\right)\end{array}$ & $\begin{array}{l}\text { Transmit- } \\
\text { tance }\end{array}$ & Reflectance \\
\hline Glass & 0.003 & 0.9 & 0.8 & 0.08 \\
\hline
\end{tabular}

Table 5 EnergyPlus infiltration default coefficient [14]

\begin{tabular}{lllll}
\hline Model & $\begin{array}{l}\text { Constant } \\
\text { coefficient }\end{array}$ & $\begin{array}{l}\text { Temperature } \\
\text { coefficient }\end{array}$ & $\begin{array}{l}\text { Wind speed } \\
\text { coefficient } \\
\text { (linear term) }\end{array}$ & $\begin{array}{l}\text { Wind speed } \\
\text { coefficient } \\
\text { (quadratic } \\
\text { term) }\end{array}$ \\
\hline $\begin{array}{l}\text { Constant } \\
\text { infiltration }\end{array}$ & 1 & 0 & 0 & 0 \\
\hline
\end{tabular}

The total thermal losses of the contemporary room (whose habitable volume is $47.12 \mathrm{~m}^{3}$ ) are $126.85 \mathrm{~W} /{ }^{\circ} \mathrm{C}$, where the volumetric loss coefficient is $2.69 \mathrm{~W} / \mathrm{m}^{3}{ }^{\circ} \mathrm{C}$. For a habitable volume of $68.97 \mathrm{~m}^{3}$ in the vernacular house, the total thermal loss is $77.51 \mathrm{~W} /{ }^{\circ} \mathrm{C}$, in case the volumetric loss coefficient is $1.12 \mathrm{~W} / \mathrm{m}^{3}{ }^{\circ} \mathrm{C}$.

Using the energy professional's method, the resulting unified degree of summer and winter days is $3.6^{\circ} \mathrm{C}$ and $11.6{ }^{\circ} \mathrm{C}$, respectively. Taking into account all the results stated previously, the energy demand for the two evaluated rooms was estimated in the typical summer and winter day, to reach the minimum level of thermal comfort, a temperature of $30.5{ }^{\circ} \mathrm{C}$ in a warm period and $17.1^{\circ} \mathrm{C}$ in the cold period.

The volumetric loss coefficient is varied from $0.4 \mathrm{~W} / \mathrm{m}^{3 \circ} \mathrm{C}$ for a bioclimatic habitat, passing through an average of $1.2 \mathrm{~W} /$ $\mathrm{m}^{3}{ }^{\circ} \mathrm{C}$ to $1.9 \mathrm{~W} / \mathrm{m}^{3 \circ} \mathrm{C}$ for a habitat that is considered as a
Table 6 Comparison of measured and simulated results of temperature and humidity on a warm day

Table 7 Comparison of measured and simulated results of temperature and humidity on a cold day

Fig. 15 ASHRAE Adaptive chart of summer day vernacular dwelling assessment [8]

\begin{tabular}{lllllll}
\hline Sample & Measured $T\left({ }^{\circ} \mathrm{C}\right)$ & Simulated $T\left({ }^{\circ} \mathrm{C}\right)$ & Error \% & $\begin{array}{l}\text { Measured } \\
\text { RH }(\%)\end{array}$ & $\begin{array}{l}\text { Simulated } \\
\text { RH }(\%)\end{array}$ & Error \% \\
\hline Vernacular & 27.06 & 26.29 & 2.84 & 44 & 44.3 & 0.67 \\
Modern & 31.97 & 31.57 & 1.25 & 28.7 & 29.2 & 1.71 \\
\hline
\end{tabular}

\begin{tabular}{lllllll}
\hline Sample & $\begin{array}{l}\text { Measured } T \\
\left({ }^{\circ} \mathrm{C}\right)\end{array}$ & $\begin{array}{l}\text { Simulated } T \\
\left({ }^{\circ} \mathrm{C}\right)\end{array}$ & Error $\%$ & $\begin{array}{l}\text { Measured RH } \\
(\%)\end{array}$ & $\begin{array}{l}\text { Simulated RH } \\
(\%)\end{array}$ & Error \% \\
\hline Vernacular & 7.18 & 7.37 & 2.57 & 61 & 60.75 & 0.40 \\
Modern & 6.6 & 6.08 & 7.87 & 48.2 & 48.9 & 1.43 \\
\hline
\end{tabular}

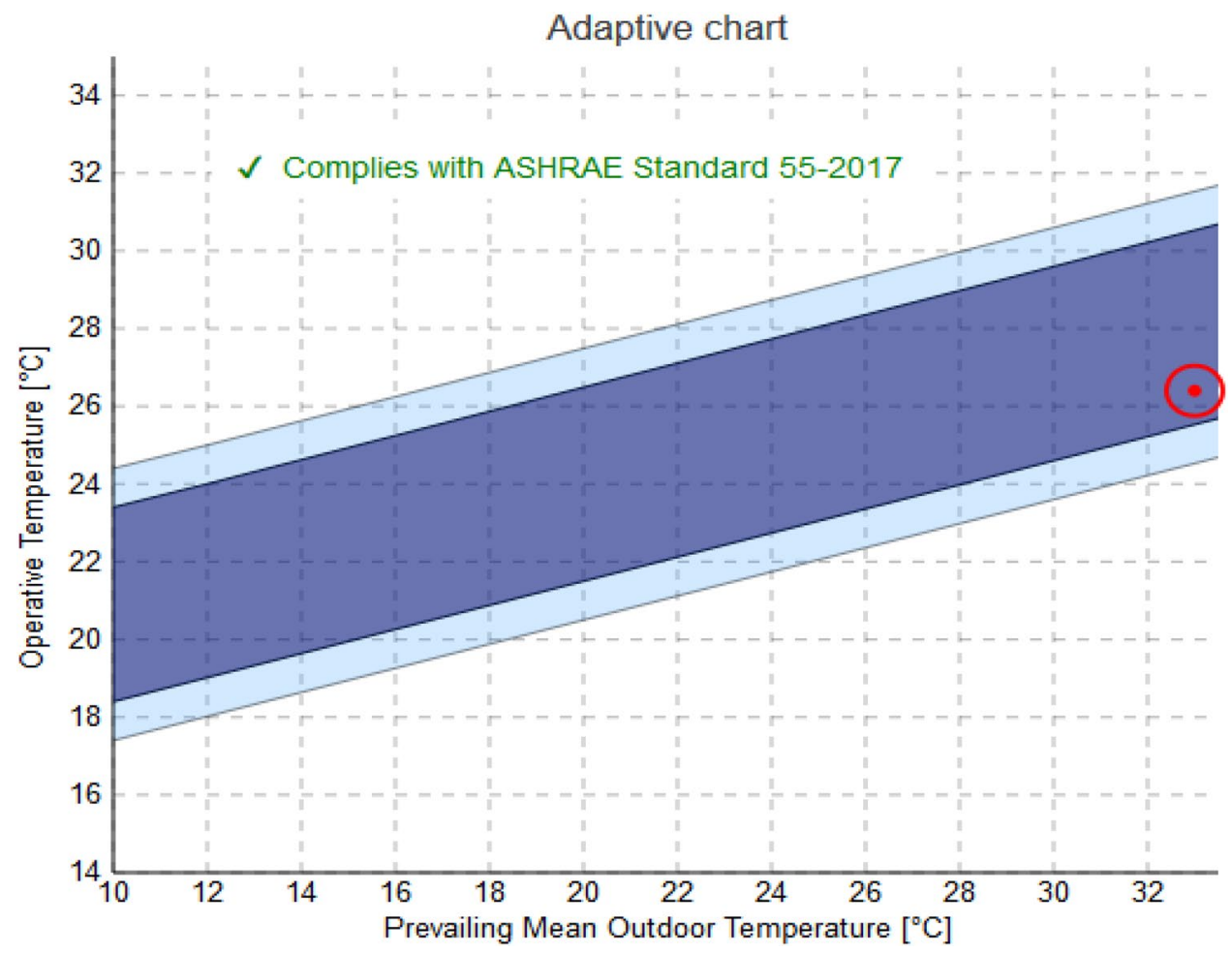


Table 8 Thermal loss of the contemporary room

\begin{tabular}{llllllll}
\hline & Wall $_{1}$ & Wall $_{2}$ & Wall $_{3}$ & Floor & Roof & Window & Door \\
\hline $\mathrm{K}\left(\mathrm{w} / \mathrm{m}^{2}{ }^{\circ} \mathrm{C}\right)$ & 1.06 & 1 & 1.8 & 2.24 & 1.81 & 5 & 2 \\
$\mathrm{~S}\left(\mathrm{~m}^{2}\right)$ & 19.6 & 12.32 & 10.22 & 15.39 & 15.39 & 1.8 & 2.1 \\
$\mathrm{KS}\left(\mathrm{w} /{ }^{\circ} \mathrm{C}\right)$ & 20.77 & 12.32 & 18.39 & 34.47 & 27.70 & 9 & 4.2 \\
Total thermal loss $\mathrm{w} /{ }^{\circ} \mathrm{C}$ & 126.85 & & & & & & \\
\hline
\end{tabular}

\begin{tabular}{lllllll}
\hline & Wall $_{1}$ & Wall $_{2}$ & Floor & Roof & Window & Door \\
\hline $\mathrm{K}\left(\mathrm{w} / \mathrm{m}^{2}{ }^{\circ} \mathrm{C}\right)$ & 0.93 & 1 & 0.33 & 0.32 & 5 & 2 \\
$\mathrm{~S}\left(\mathrm{~m}^{2}\right)$ & 28.11 & 26.2 & 22.52 & 22.52 & 1.02 & 2.72 \\
$\mathrm{KS}\left(\mathrm{w} /{ }^{\circ} \mathrm{C}\right)$ & 26.14 & 26.2 & 7.43 & 7.2 & 5.1 & 5.44 \\
Total thermal loss $\left(\mathrm{w} /{ }^{\circ} \mathrm{C}\right)$ & 77.51 & & & & & \\
\hline
\end{tabular}

Table 9 Thermal loss of the vernacular room
$\mathrm{kWh}$ and $26.09 \mathrm{kWh}$ estimated in vernacular and modern house, respectively) confirmed the energy demand reduction percentage on the cold day. However, the summer day simulation reveals a $100 \%$ cooling energy efficiency in the traditional house; nonetheless, $4.93 \mathrm{kWh}$ of energy was needed to achieve thermal comfort in the modern house.

\section{Conclusion}

The industrial ideology translates constructive simplicity into social poverty. It defines the absence of industrial devices by backwardness and pretends that technological modesty is not voluntary but reflects delay and inferiority. This new signification attacks the vernacular architecture, convincing that only active systems can satisfy occupant needs.

After the global energy crisis, people's thoughts have changed, and the theme of ecological architecture has been widely discussed, focusing on climate and natural sources. The notion of the vernacular house has appeared again, a notion that has not caught up in Algeria.

On that point, the present paper seeks to highlight the thermal comfort aspect and that of energy saving in the southern Algerian vernacular habitat that provides an example of people living with low-income and theirs solution and attitudes about thermal comfort. It concretizes a comparative study relating to the thermal and energy performance of two types of building; vernacular and low-income modern house.

The thermal behavior evaluation shows that summer thermal comfort can be assured passively, by following the vernacular architecture principles, which present a response to mankind's needs in his climate. The vernacular house was comfortable during the warm day, without using the air-conditioning, active systems, which allowed reducing the energy

Fig. 16 The energy demand of studied spaces (energy professional method) 


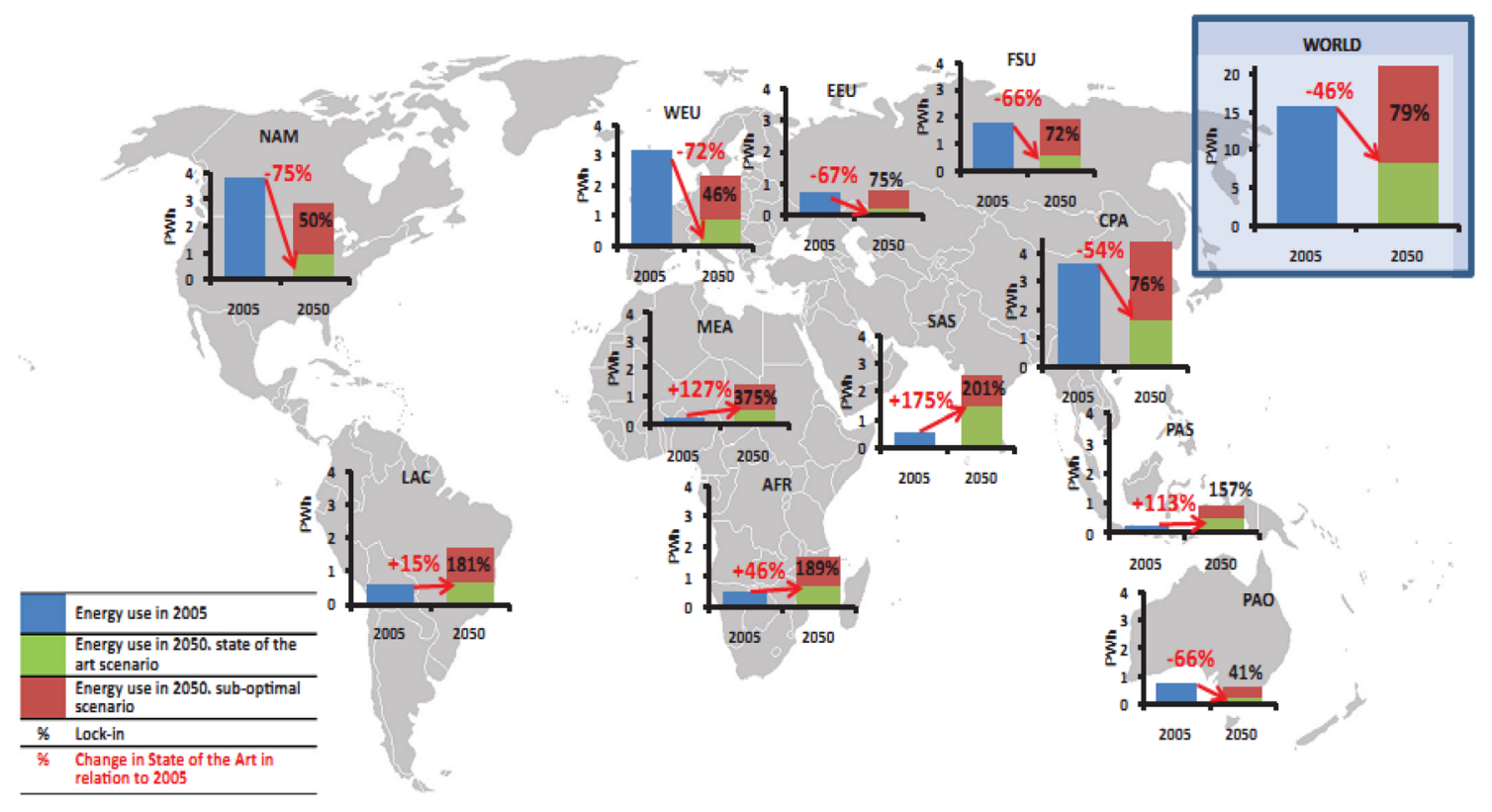

Fig. 17 Final building heating and cooling energy demand scenarios until 2050 [8]

demand. In contrast, the contemporary house, whose use of air-conditioning, modern systems were essential to meet the occupant needs in terms of thermal comfort, caused a significant energy demand. This was also the case during the cold day in both houses rated; temperatures outside comfort ranges were marked, necessitating the use of active heating systems.

The calculation method presented in the French thermal regulation [46] made it possible to count the energy demand in heating and air-conditioning of the two study objects. The no-take into consideration of resulting ambient temperatures achieved unsatisfactory results; however, the difference between the houses' energy performances was estimated, including a $39 \%$ reduction in energy demand thanks to the bioclimatic strategies that are part of the vernacular architecture. This percentage has, as well, been confirmed by the cold day EnergyPlus simulation; nevertheless, the summer day presents a $100 \%$ energy demand reduction (the thermal comfort was achieved in a passive way).

These results demonstrate that vernacular architecture is a subject of renewed interest, which must be exerted through a stronger involvement of construction actors who benefit from all software necessary to evaluate their projects before realizing them while guaranteeing an excellent level of results precision. Moreover, exerting vernacular architecture principles helps in reaching the building heating and cooling energy demand scenarios by 2050 (constructed by the Global Energy Assessment team, Fig. 17), which can result in significant benefits including mitigation of the building sector's contribution to climate change, improvements in energy security and sovereignty, alleviation of energy poverty and improvement of social welfare.
Acknowledgements We would like to thank the SREML laboratory of the Ammar Telidji University, for its support in realizing characterization tests and site measurements. We thank Professor BENCHEIKH Hamida for sharing his pearls of wisdom with us during the course of this research. We would also like to express our gratitude to DAHMRI Abdelhak for assistance with dwelling designs and modeling, and we thank the four "anonymous" reviewers for their so-called insights.

Author contributions DB performed the conception and design of the study, acquired the data, analyzed and interpreted the results, wrote the paper. MB supervised the research, provided critical revision of the article, co-wrote the paper, and approved the version to be published.

\section{Compliance with ethical standards}

Conflict of interest We have no financial or personal relationships with other people or organizations that could inappropriately influence our work. The publication of this paper is only for the purpose of enriching the science.

Open Access This article is distributed under the terms of the Creative Commons Attribution 4.0 International License (http://creativeco mmons.org/licenses/by/4.0/), which permits unrestricted use, distribution, and reproduction in any medium, provided you give appropriate credit to the original author(s) and the source, provide a link to the Creative Commons license, and indicate if changes were made.

\section{References}

1. Abdul Tharim, A.H., Abdul Samad, M.H.: A review on sustainable design and indoor thermal comfort of a green building. ARPN J. Eng. Appl. Sci. 11(6), 3712-3717 (2016)

2. Albatayneh, A., Alterman, D., Page, A., Moghtaderi, B.: The impact of the thermal comfort models on the prediction of building energy consumption. Sustainability 10, 3609 (2018) 
3. ARIEFF, A.: Algeria: current issues. CRS report, prepared for a members and comities of congress. Congressional Research Service (2013). https://fas.org/sgp/crs/row/RS21532.pdf. Accessed 6 Jan 2019

4. Bencheikh, D., Bederina, M.: The Rehabilitation effects on the thermal behavior of Algerian earthen built heritage. MATEC Web of Conferences 149-02049 (2018)

5. Besagni, G., Marco, B.: The determinants of residential energy expenditure in Italy. Energy 165, Part A(15), 369-386 (2018)

6. Brounen, D., Kok, N., Quigley, J.M.: Residential energy use and conservation: economics and demographics. Eur Econ Rev 56, 931-945 (2012)

7. Burmana, E., Mumovicb, D., Kimpianc, J.: Towards measurement and verification of energy performance under the framework of the European directive for energy performance of buildings. Energy 77, 153-163 (2014)

8. CBE: Thermal comfort tool for ASHRAE-55 (2019). http://comfo rt.cbe.berkeley.edu/. Accessed 05 Jan 2019

9. Chaer, I.: Estimation of cooling energy demand and carbon emissions from urban buildings using a quasi-dynamic model (2014).https://doi.org/10.13140/2.1.1978.3685

10. CNERIB: Document technique réglementaire DTR C3-T (2011)

11. De Angelis, E., Tagliabue, L., Re Cecconi, F., Mainini, A.: A simple method for the comparison of bioclimatic design strategies based on dynamic indoor thermal comfort assessment for school buildings. Proc. Eng. 180, 870-880 (2017). https://doi. org/10.1016/j.proeng.2017.04.248

12. De Dear, R.J., Brager, G.S., Reardon, J., Nicol, F.: Developing an adaptive model of thermal comfort and preference/discussion. ASHRAE Trans. 104, 145 (1998)

13. Doat, P., Hayes, A., Houben, H., Matuk, S., Vitoux, F.: Construire en terre. Paris.La Harmattan, p. 281 (1979)

14. EnergyPlus Manual (2008) Documentation version 3.0. Department of Energy, Washington, D.C.

15. ETP 2017: Iea.Org (2019). https://www.iea.org/etp/etp2017/. Accessed 15 Dec 2018

16. Fathy, H.: Natural Energy and Vernacular Architecture Principles and Examples with Reference to Hot Arid Climates, p. 172. The University of Chicago Press, Chicago (1986)

17. Fiaschi, D., Bandinelli, R., Conti, S.: A case study for energy issues of public buildings and utilities in a small municipality: investigation of possible improvements and integration with renewables. Appl. Energy 97, 101-114 (2012). https://doi. org/10.1016/j.apenergy.2012.03.008

18. FMDJ: Fiche méthode Degrés Jours. sur le site meteo.fr de Météo France(2018). http://climatheque.meteo.fr/Docs/DJC-methode.pdf

19. Frontczak, M., Wargocki, P.: Literature survey on how different factors influence human comfort in indoor environments. Build. Environ. 46(4), 922-937 (2011)

20. Galvin, R., Sunikka-Blank, M.: Economic viability in thermal retrofit policies: learning from ten years of experience in Germany. Energy Policy 54, 343-351 (2013)

21. GEA: Global Energy Assessment: Toward a Sustainable Future. Cambridge University Press, Cambridge (2012)

22. Givoni, B.: L'homme l'architecture et le climat. Paris, le moniteur, $460 \mathrm{p}$ (1987)

23. Gong, Y., Song, D.: Life cycle building carbon emissions assessment and driving factors decomposition analysis based on LMDI: a case study of Wuhan City in China. Sustainability 7(12), 1667016686 (2015). https://doi.org/10.3390/su71215838

24. Großmann, K., Bartke, S., Bierwirth, A., Jensen, T., Kabisch, S., Malottki, C., Rüganer, J.: Energetische Sanierung: Sozialräumliche Strukturen von Städten berücksichtigen. GAIA 23(4), 309-312 (2014)
25. Hajat, S., O'Connor, M., Kosatsky, T.: Health effects of hot weather: From awareness of risk factors to effective health protection. Lancet 375(9717), 856-863 (2010)

26. Harris, F., McCaffer, R., Edum-Fotwe, F.: Modern Construction Management, p. 576. Wiley-Blackwell, Hoboken (2013)

27. Herero, S.T.: Energy poverty indicators: A critical review of methods. Indoor Built. Environ. 26(7), 1018-1031 (2010)

28. Houben, H., Guilaud, H.: Traité des constructions en terre, p. 300. Parenthèses, Paris (1989)

29. IEA (2019) The global exchange for energy efficiency policies, data and analyses. Energy Access Outlook. https://www.iea.org/ topics/energyefficiency/. Accessed 27 Apr 2019

30. Khledj, S., Bencheikh, H.: impact of a retrofitting project on thermal comfort and energy efficiency of a historic school in Miliana, Algeria. Int. J. Archit. Herit. (2019). https://doi. org/10.1080/15583058.2019.1621960

31. Kolokotsa, D., Diakaki, C., Grigoroudis, E., Stavrakakis, G., Kalaitzakis, K.: Decision support methodologies on the energy efficiency and energy management in buildings. Adv. Build. Energy Res. 3(1), 121-146 (2009). https://doi.org/10.3763/ aber.2009.0305

32. Marmot Review Team: The Health Impacts of Cold Homes and Fuel Poverty. Friends of the Earth and the Marmot Review Team, London (2011)

33. Matari, N. et al.: Effet de l'enveloppe du bâtiment sur le confort thermique. Application au climat aride". Congrès Français de Thermique SFT 2015, La thermique de l'habitat et de la ville, La Rochelle, pp. 1-8 (2015)

34. Massimo, F., Pachauria, S.: Residential energy expenditures and elasticities of electricity demand in urban Indian households. Energy Policy 32, 429-436 (2004)

35. Michelsen, C., Müller-Michelsen, S.: Energieeffizienz im Altbau: Werden die Sanierungspotenziale überschätzt? Ergebnisse auf Grundlage des ista-IWH-Energieeffizienzindex. Wirtschaft Im Wandel 9, 447-455 (2010)

36. Ministère de 1'habitat: Recommandation architecturales. Ed ENAG, Alger (1993)

37. NF EN ISO 8894-1: Refractory materials: determination of thermal conductivity-part1: hot-wire methods (cross-array and resistance thermometer). Matériaux réfractaires (2010)

38. NF P94-064: Soils: investigation and testing. Density of a dehydrated rock sample. Hydrostatic weighing method. Sols: reconnaissance et essais (1993)

39. Nussbaumer, P., Nerini, F.F., Onyeji, I., Howells, M.: Global insights based on the multidimensional energy poverty index (MEPI). Sustainability 5(5), 2060-2076 (2013)

40. Oliver, P.: Built to Meet Needs; Cultural Issues in Vernacular Architecture, p. 475. Architectural Press, Oxford (2006)

41. ONM (2017) office national de la météorologie. Données climatiques journalières

42. Pérez-Lombard, L., Ortiz, J., Pout, C.: A review on buildings energy consumption information. Energy Build. 40(3), 394-398 (2008). https://doi.org/10.1016/j.enbuild.2007.03.007

43. PPSMVSS: Plan permanent de sauvegarde et de mise en valeur du secteur sauvegardé; Le vieux ksar de Laghouat No. 11-141 du 28 mars 2011/JO No. 20 du 30/03/2011 (2011)

44. Ravero, A.: le M'Zab, une leçon d'architecture, p. 221. Arles, Sindbad (2003)

45. Ritchie, H., Max, R.: $\mathrm{CO}_{2}$ and other greenhouse gas emissions. Our World In Data (2019). https://ourworldindata.org/co2-andother-greenhouse-gas-emissions. Accessed 12 May 2019

46. RT 2012 Ministère de l'Écologie, du Développement durable, des Transports et du Logement. La Règlementation Thermique 
Grenelle de l'Environnement (2012). http://www.infoenergie.eu/ riv+ener/LCU_fichiers/LT-RT2012.pdf

47. Singh, A., Berghorn, G., Joshi, S., Syal, M.: Review of life-cycle assessment applications in building construction. J. Archit. Eng. 17(1), 15-23 (2011). https://doi.org/10.1061/(asce)ae.19435568.0000026

48. Spitz, C.: Analyse de la fiabilité des outils de simulation et des incertitudes de métrologie appliquée à l'efficacité énergétique des bâtiments. Thèse du doctorat, Université de Grenoble, France (2012)

49. The Eurowinter Group: Cold exposure and winter mortality from ischaemic heart disease, cerebrovascular disease, respiratory disease, and all causes in warm and cold regions of Europe. Lancet 1997(349), 1341-1346 (1997)
50. Wolff, A., Schubert, J., Gill, B.: Risiko energetische Sanierung?. In Energie und soziale Ungleichheit, pp. 611-634. Springer, Fachmedien Wiesbaden (2017)

51. $\mathrm{Xu}, \mathrm{Z}$.: Analysis on the causes of the slow development of city low-carbon construction. Urban Probl. 5, 51-53 (2012)

52. Yang, L., Yan, H., Lam, J.C.: Thermal comfort and building energy consumption implications: a review. Appl. Energy 115, 164-173 (2014). https://doi.org/10.1016/j.apenergy.2013.10.062

53. Ying-Ming, S.: Improvement of ventilation and thermal comfort using the atrium design for traditional folk houses-fujian earthen building. Int. J. Urban Civil Eng. 11(4), 469-477 (2017)

Publisher's Note Springer Nature remains neutral with regard to jurisdictional claims in published maps and institutional affiliations. 